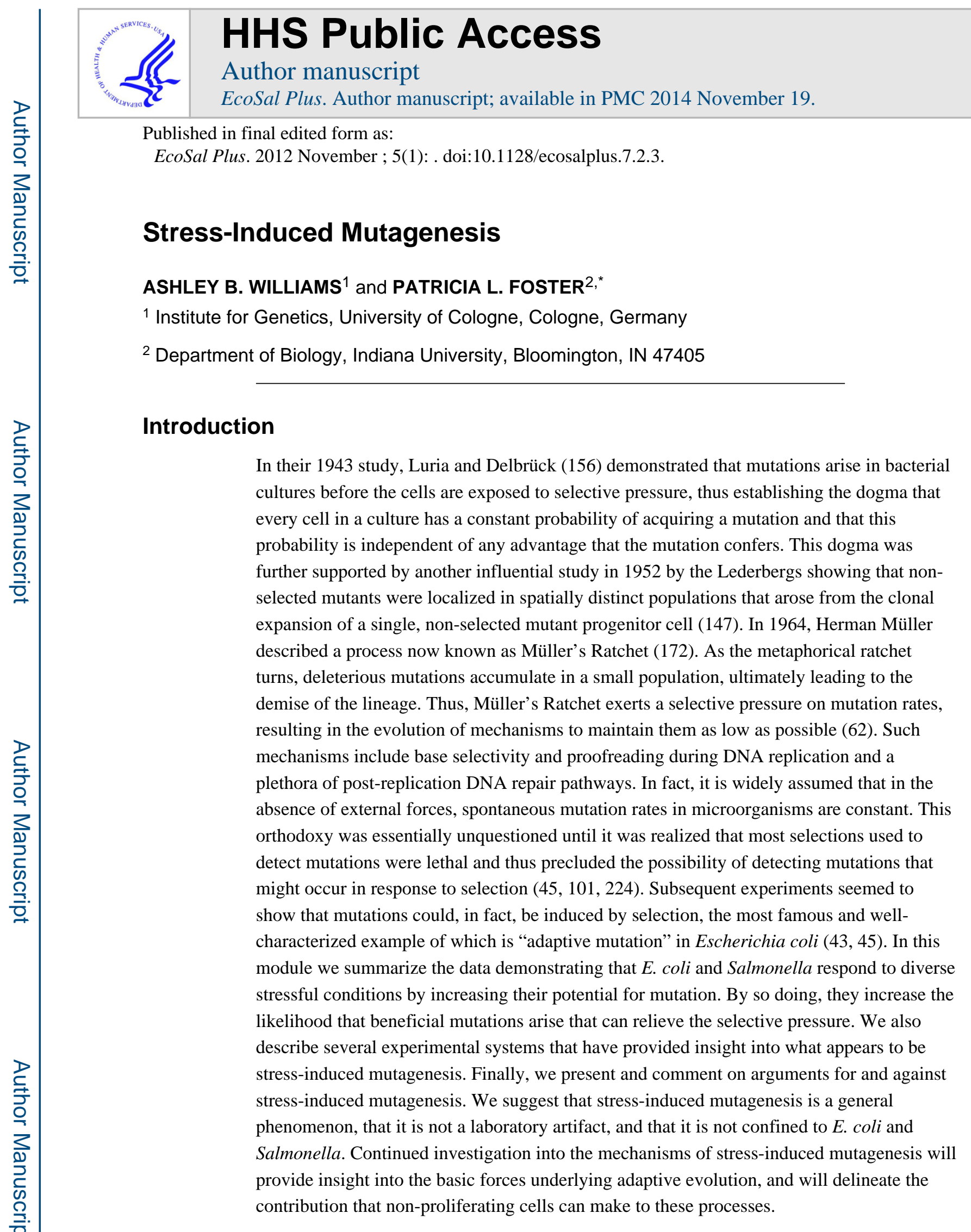

Published in final edited form as:

EcoSal Plus. 2012 November ; 5(1): . doi:10.1128/ecosalplus.7.2.3.

\title{
Stress-Induced Mutagenesis
}

\author{
ASHLEY B. WILLIAMS ${ }^{1}$ and PATRICIA L. FOSTER ${ }^{2, *}$ \\ (titute for Genetics, University of Cologne, Cologne, Ge \\ Department of Biology, Indiana University, Bloomington, IN 47405
}

In their 1943 study, Luria and Delbrück (156) demonstrated that mutations arise in bacterial cultures before the cells are exposed to selective pressure, thus establishing the dogma that every cell in a culture has a constant probability of acquiring a mutation and that this probability is independent of any advantage that the mutation confers. This dogma was further supported by another influential study in 1952 by the Lederbergs showing that nonselected mutants were localized in spatially distinct populations that arose from the clonal expansion of a single, non-selected mutant progenitor cell (147). In 1964, Herman Müller described a process now known as Müller's Ratchet (172). As the metaphorical ratchet turns, deleterious mutations accumulate in a small population, ultimately leading to the demise of the lineage. Thus, Müller's Ratchet exerts a selective pressure on mutation rates, resulting in the evolution of mechanisms to maintain them as low as possible (62). Such mechanisms include base selectivity and proofreading during DNA replication and a plethora of post-replication DNA repair pathways. In fact, it is widely assumed that in the absence of external forces, spontaneous mutation rates in microorganisms are constant. This orthodoxy was essentially unquestioned until it was realized that most selections used to detect mutations were lethal and thus precluded the possibility of detecting mutations that might occur in response to selection $(45,101,224)$. Subsequent experiments seemed to show that mutations could, in fact, be induced by selection, the most famous and well characterized example of which is "adaptive mutation" in Escherichia coli $(43,45)$. In this module we summarize the data demonstrating that E. coli and Salmonella respond to diverse stressful conditions by increasing their potential for mutation. By so doing, they increase the likelihood that beneficial mutations arise that can relieve the selective pressure. We also describe several experimental systems that have provided insight into what appears to be stress-induced mutagenesis. Finally, we present and comment on arguments for and against phenomenon, that it is not a laboratory artifact, and that it is not confined to E. coli and Salmonella. Continued investigation into the mechanisms of stress-induced mutagenesis will contribution that non-proliferating cells can make to these processes.

\footnotetext{
*Corresponding author. Mailing address: Department of Biology, Indiana University, 1001 East Third Street, Bloomington, IN 47405. Phone: (812) 855-4084, Fax: (812) 855-6705, plfoster@indiana.edu.
} 


\section{DNA synthesis in non-dividing cells}

DNA damage can occur in starved, non-dividing cells due to a variety of environmental and endogenous factors. While extensive DNA replication does not occur under these conditions, a number of early studies showed that some DNA is synthesized in starving $E$. coli cells, a necessary precursor if the DNA damage is to lead to mutations $(53,99,103$, 174, 213, 214). In fact, the phenomenon of stationary-phase mutation was first described in the late 1960s and attributed to repair DNA synthesis (98). A study published in 1979 by Tang and colleagues (245) demonstrated that when stationary-phase $E$. coli cells were suspended in buffer lacking nitrogen and carbon sources but containing tritium-labeled thymidine, about $2 \%$ of their DNA became labelled over a period of about six hours. However, during this period, there was no net change in the amount of DNA. Because DNA polymerase I (Pol I, encoded by the polA gene) was required for incorporation, the authors concluded that the DNA was being continuously degraded and then resynthesized by Pol I. More recent studies have implicated various mechanisms by which DNA synthesis can be stimulated in quiescent cells (reviewed in references 30,32). Taken together, these data demonstrate that DNA metabolism with the capacity to produce mutations occurs in nondividing cells, a requirement for many of the processes that are discussed in the following sections.

\section{Stress Responses Increase Mutagenic Potential The SOS Response to DNA Damage}

Cells are constantly exposed to DNA damage from both endogenous and exogenous sources. As maintenance of genetic integrity is critical for life, cells have evolved sophisticated mechanisms to minimize the deleterious effects of these damaging agents. One example of such a mechanism is the SOS response. The SOS response is covered in detail in Eco-Sal III Module 5.4.3. "The SOS Regulatory Network, and Module 7.2.8. "The SOS Response", and so only a brief description is included here. The initial signal for the induction of the SOS response is the formation of single-stranded DNA (ssDNA) that is then bound by the RecA recombinase, forming a nucleoprotein complex. When in the nucleoprotein complex RecA is "activated" and promotes the autocleavage of the SOS repressor, LexA, resulting in the derepression of the genes of the SOS regulon. At least 30 genes are regulated by LexA (54, $70,120)$. Although the functions of the SOS proteins are diverse, most promote cell recovery from DNA damage by participating in pathways for DNA repair or recombination, or by modulating DNA replication to cope with lesions that block the replication fork.

The most obvious stress that induces the SOS response is exposure to DNA damaging agents. Bulky lesions in the DNA, as well as single- and double-strand breaks, are acted upon by various repair functions that produce the SOS-inducing signal, single-stranded DNA. In addition, single-stranded DNA can be formed by a variety of intracellular processes such as failed chromosome segregation, defects in DNA replication and recombination, defects in nucleotide metabolism, and DNA damage from metabolic intermediates (178). During conjugal transfer of the F plasmid, single-strand DNA enters the recipient cell and, after forming a complex with RecA, can induce the SOS response; however, F also encodes an inhibitor of SOS induction, PsiB, which limits the SOS response 
during conjugal transfer (9). In addition to conjugation, loss of the double-stranded $\mathrm{F}$ plasmid can also induce the SOS response because the plasmid-encoded CcdB toxin inhibits DNA gyrase, leading to double strand breaks (55).

External forces and environmental conditions that do not obviously damage the DNA can also induce the SOS response. For example, exposure to high hydrostatic pressure induces the SOS response via the DNA double-strand break repair pathway (1-3). While the initial trigger is external, the double strand breaks are caused by a cryptic endonuclease encoded on the $E$. coli chromosome; processing of the double-strand breaks by RecBCD produces the SOS-inducing single-stranded DNA. Changes in nutrient availability can also induce the SOS response. For example, when cells starved for a required amino acid are allowed to resume growth with glycerol as a carbon source, the SOS response can be induced via a cyclic-AMP-dependent pathway (117). Finally, cell wall stress, particularly exposure to certain antibiotics, can induce the SOS regulon through the DpiBA two-component system (167).

While the RecA-ssDNA complex is typically required for LexA cleavage and induction of the SOS response, this requirement is relaxed under conditions that destabilize LexA independently of DNA damage. LexA becomes unstable under weakly alkaline conditions in vitro (150) an effect that could help cells cope with DNA damage caused by alkaline environments. LexA is also inactivated in aging colonies (244) and in liquid cultures as they reach saturation (63).

\section{Role of error-prone DNA polymerases in stress-induced mutagenesis (also see Eco-Sal III Module 7.2.2. "Translesion DNA Synthesis.")}

Because single-stranded DNA can arise from a variety of conditions, the SOS response may serve as a mechanism to introduce genetic variability in addition to helping cells to recover from DNA damage. E. coli's two error-prone DNA polymerases, DNA polymerase IV (Pol IV, encoded by the $\operatorname{din} B$ gene) and DNA polymerase V (Pol V, encoded by the umuDC genes), which are upregulated as part of the SOS response, may provide such a function. A third DNA polymerase, DNA polymerase II (Pol II, encoded by the polB gene), is also induced as part of the SOS response and is capable of coping with various types of DNA damage (115); however, with the exception of error-prone synthesis past certain DNA lesions (175), Pol II is generally error-free. Pol IV and Pol V belong to the conserved Yfamily of DNA polymerases, members of which are characterized by low processivity and low fidelity even when the template DNA is undamaged. Both polymerases have the ability to replicate past DNA lesions, although they differ in the spectrum of lesions that they can accommodate. Pol IV can also extend DNA synthesis from misaligned or mispaired primer/ template termini, a property that may allow Pol IV to participate in replication restart. Replication restart is also likely to be the underlying role of Pol IV in adaptive mutation (which is discussed below).

Pol IV interacts with the replication-associated DNA helicase Rep, and this interaction enhances both Pol IV's polymerase activity and Rep's helicase activity (226). In addition, Rep is required for normal levels of Pol IV-dependent adaptive mutation (see below). Given 
the known role that Rep plays in replication restart, these results suggest that Rep assists in loading Pol IV on the DNA after replication has been stalled $(226,235)$.

In cells that are growing exponentially in rich medium when the SOS regulon is not induced, Pol V is undetectable (263); consequently, loss of Pol V has little effect on spontaneous mutation rates (133). In contrast, in uninduced cells there are about 250 copies of Pol IV (124), a relatively high copy number compared to the 10-20 copies of Pol III (267). Despite its abundance, under normal growth conditions Pol IV also makes little contribution to spontaneous mutation rates, at least on the chromosome. In contrast, Pol IV is responsible for many of the mutations that occur in stationary phase cells (discussed below). These properties suggest that the mutagenic activity of Pol IV is tightly regulated or targeted in normally growing cells, but becomes activated in non-growing cells. Table 1 lists several factors that have been shown to regulate the amount, stability, or activity of Pol IV. Since these factors are involved in various stress responses, their regulation of Pol IV will be discussed in more detail below. In addition, data have been presented that Pol IV's activity is controlled by direct interactions with RecA and UmuD (94).

Non-induced levels of Pol IV can contribute to mutation on extra-chromosomal elements. For example, Pol IV is required for untargeted mutagenesis of $\lambda$ phage in UV irradiated $E$. coli cells (37). In normally growing cells, Pol IV made a significant (about 4-fold) contribution to mutation rates of a lac reporter on the $\mathrm{F}^{\prime} 128$ episome (133). Part of this effect was because the cells carried two copies of the $\operatorname{din} B$ gene, one on the chromosome and one on the $\mathrm{F}^{\prime}$ episome; but, mutation rates of chromosomal genes were not affected by the extra copy of $\operatorname{din} B$ (133). In a separate study, deletion of the $\operatorname{din} B$ gene from both the chromosome and the episome caused a 3 -fold reduction of the reversion rate of a mutant tetA gene located on the episome (235).

Upon induction of the SOS response, the levels of Pol IV and Pol V increase dramatically, to about 2000 and 200 molecules per cell, respectively $(124,263)$. By using E. coli strains constitutive for the SOS response, the effects of up-regulation of Pol IV and Pol V on the "SOS mutator activity" can be evaluated independently of DNA damage. In one study, loss of Pol IV resulted in 50 to $70 \%$ fewer base substitution mutations in a lac reporter, whereas loss of Pol V completely abolished the SOS mutator activity (132). Competition between $E$. coli's five DNA polymerases was examined by determining their individual and joint mutational spectra in an $r p o B$ reporter (which scores mutation to rifampicin resistance) (56). Pol IV and Pol V were required for most transversion mutations, while transition mutations mostly required Pol I. Interestingly, the presence of Pol IV or Pol II altered mutation by Pol I at a specific site in the rpoB target, suggesting that the different polymerases compete for substrates and can modulate the other's activities. Competition could occur at the point of base-insertion, or at the point of extension from a mispaired terminus.

While expression of Pol IV from the $\mathrm{F}^{\prime}$ episome and other low copy plasmids has a mild (2to 10- fold) mutagenic effect $(132,133)$, overexpression of Pol IV from a high copy plasmid typically increases spontaneous mutation frequencies up to 200 - fold $(257,260,262)$, and, in one case, 1000-fold (123). The actual degree of enhancement depends not only on the 
plasmid used, but also on whether the target is on the chromosome or on the episome and whether the mutation is a base substitution or a frameshift.

Pol V's translesion bypass activity requires that the polymerase subunit, UmuC, is in a complex with two proteolytically processed copies of $\mathrm{UmuD}$, called $\mathrm{UmuD}^{\prime}$, and that this heterotrimer interacts with a RecA-ssDNA filament (179). These complex requirements limit measurements of Pol V-dependent mutagenesis using simple overexpression studies. However, Pol V homologs with simpler requirements are found on naturally occurring genetic elements, and these polymerases can be used as proxies for Pol V. The IncJ conjugal transposon R391 encodes a Pol V homolog, RumAB, and a more mutagenic form of RumAB, RumA'B, was engineered to model $\mathrm{UmuD}^{\prime} \mathrm{C}$ (242). In a strain lacking $u m u D C$, constitutive for the SOS response, and carrying the recA718 allele, which encodes a RecA protein that is constitutively activated (261), overexpression of RumA'B from a low copy plasmid increased the spontaneous mutation frequency in E. coli cells 3- to 12-fold more than expressing $\mathrm{UmuD}^{\prime} \mathrm{C}$ from the same plasmid (164). But strains carrying the R394 plasmid, which also encodes a Pol V homolog, have low mutation rates after MMS exposure (128). These observations suggest that the mutagenic potential of these Pol V-like proteins may be relevant only under novel conditions, and/or that the intact plasmids carry inhibitors of the mutagenic activity of the polymerases (128).

\section{The General Stress Response}

When E. coli and Salmonella are subjected to nutrient limitation, a complex and sophisticated cascade of events is induced. Because this response is not specific to a particular environmental condition (such as depletion of a specific amino acid), it has been called the "general" stress response (for a reviews, see reference 13, Eco-Sal III Section 5.3. "Sensing and Responding to Nutrient Availability" and Section 5.6. "Physiological and Genetic Adaptation to Growth Arrest"). The central regulator of the general stress response is the sigma factor RpoS (also known as KatF, $\sigma^{38}$, and $\sigma^{\mathrm{S}}$ ). Sigma factors are the subunits of RNA polymerase (RNAP) that target the transcription machinery to specific promoters. (The RNA polymerase holoenzyme containing a specific sigma factor, e.g. $\sigma^{70}$ or $\sigma^{38}$, is indicated as $\mathrm{E \sigma}^{70}$ or $\mathrm{E}^{38}$ ). During exponential growth, most RNA polymerase molecules contain the vegetative sigma factor $\sigma^{70} \sigma(\mathrm{RpoD})$, and the amount and activity of $\sigma^{38}$ is tightly controlled. Under stressful conditions, both the amount and the activity of $\sigma^{38}$ is upregulated and $\mathrm{E}^{38}$ becomes prevalent, resulting in the transcription of genes encoding proteins that promote survival. Over 200 genes are directly or indirectly regulated by $\mathrm{E}^{38}$; these are collectively known as the $\mathrm{E}^{38}$ or $\operatorname{RpoS}$ regulon $(59,142,180,190,256,259)$. The general stress response is linked to two mechanisms that can increase mutation rates: induction of Pol IV, and down-regulation of mismatch repair.

Approximately ten hours after the onset of stationary phase, the level of Pol IV increases 3fold in wild-type cells but declines precipitously in rpoS mutant cells, so that after 48 hours in stationary phase there is a 25- to 50-fold difference in Pol IV levels between wild-type and rpoS mutant cells (145). This effect appears to be mostly or entirely due to direct transcription of $\operatorname{din} B$ by $\mathrm{E \sigma}^{38}(145,234)$. As mentioned above, the SOS response may be partially induced in stationary-phase cells, but regulation of $\operatorname{din} B$ by RpoS is independent of 
the SOS response (145). The roles that Pol IV may play in stationary phase are not fully understood. RpoS-dependent upregulation of Pol IV is required for adaptive $\mathrm{Lac}^{+}$reversion (discussed below). In addition, when stationary phase cells are incubated for extended periods of time, cells lacking Pol IV compete poorly with wild-type cells in mixed populations (270). This loss of "growth advantage in stationary phase (GASP)" also occurs in cells missing Pol V or Pol II, suggesting that these polymerases have important functions during prolonged starvation. For example, they may be required for the repair of DNA damage occuring in stationary phase cells, or error-prone DNA synthesis may be required to generate the mutations that lead to the GASP phenotype.

In stationary-phase cells the proteins involved in mismatch repair (MMR) decline (for a review of MMR see reference 136 and Eco-Sal III Module 7.2.5. "Mismatch Repair"). Normally MMR is active in stationary-phase cells $(75,193)$; however, the levels of two MMR proteins, MutS (the mismatch binding protein) and MutH (the endonuclease that initiates repair by incising the nascent DNA strand) decline via an RpoS-dependent mechanism $(69,254)$. The degree to which this decline is responsible for increased mutations in stationary-phase cells is disputed. That the frequency of mutations in stationary phase cells declines when MMR proteins are over-expressed (24, 81, 88, 104, 275) supports the hypothesis that MMR is limiting in at least some stationary-phase cells. However, which specific MMR proteins are limiting is unclear. Three studies found that over-expression of MutS reduces stationary-phase mutations $(24,75,275)$, one study found that overexpression of MutS and MutL together had the maximum effect (75), whereas two studies found that over-expression of MutL alone was sufficient $(88,104)$. However, overproduction of one or more of these proteins also reduced mutation frequencies in growing cells (75), suggesting that MMR is no more limiting in stationary-phase cells than in exponential-phase cells.

That decline of MMR in stationary phase cells can increase mutation frequencies is also supported by a phenomenon known as "mutagenesis in aging colonies," or MAC, (24). During seven days of incubation, the mutant frequencies in aging colonies appeared to increase by two orders of magnitude. However, a mutS mutant strain had a similar mutant frequency on day one as the wild-type strain had after seven days of incubation; furthermore, the mutant frequency of the mutS mutant strain did not increase with aging. The simplest explanation for this result is that a decline in MMR is responsible for the increased mutation rate in the aging colonies. However, this conclusion has been questioned (264). Other experiments with MMR defective cells support the relevance of MMR in stationary-phase mutation. During adaptive mutation experiments, a subpopulation of the cells is in a state of hypermutation $(200,253)$. While loss of MMR (via mutation of mutL) caused a large increase in the mutation rate of the cells overall, it had no effect on the mutation rate of the hypermutating subpopulation (200). This result suggests that the increased mutation rate in the hypermutating subpopulation was due to a decline in MMR (or in another pathway that requires MutL). However, it must be emphasized that a decline in MMR cannot cause new mutations, but can only increase the probability that errors made by some other process will be preserved as mutations. The high mutation rate in some stationary phase cells may be due to an additive effect of errors made by DNA polymerases, 
such as Pol IV, and their preservation as mutations due to reduced MMR activity. These observations demonstrate the potentially complex interplay between various RpoS-regulated processes in stationary phase cells.

In addition to nutrient deprivation, several other stress conditions can affect the stability of the RpoS protein, and thus potentially influence mutation rates via the RpoS regulon. When complexed with the adaptor protein RssB (MviA in Salmonella), RpoS is degraded by the ClpXP protease $(14,171,187,276,277)$. Several anti-adapters that interact with and block the function of RssB can stabilize RpoS under specific stress conditions $(27,28)$. These antiadapters include IraP, which is induced by phosphate starvation, $\mathrm{IraD}$, which is induced by exposure to hydrogen peroxide, and IraM, which is induced by magnesium deficiency. Thus the extent to which RpoS acts as a central regulator of mutagenic potential under various conditions is yet to be fully elucidated.

In addition to the fairly straightforward functions for RpoS in stress-induced mutagenesis described above, several less well-characterized activities of RpoS may also influence mutagenic pathways. RpoS impacts stationary-phase adaptive mutation by regulating the abundance of Pol IV, but $\operatorname{din} B$ and $r p o S$ mutations are not epistatic (145). Thus, RpoS has an unknown Pol IV-independent function in adaptive mutation. After prolonged incubation (greater than five days), amplification of the mutant lac allele makes a significant contribution to adaptive mutation, and RpoS is required for this amplification via an unknown mechanism (153). RpoS, among other host factors, has also been shown to be required for formation of $a r a B$-lacZ fusions under aerobic, carbon-limiting conditions (95). These fusions are the result of chromosomal rearrangements mediated by the Mu phage inserted between the two genes (224). While the mechanisms of these mutagenic pathways are clearly different, they occur under nutrient-limiting conditions, supporting the hypothesis that $\mathrm{RpoS}$ is a central regulator of mutagenesis occurring during nutrient deprivation.

\section{Polyphosphate-Mediated Response to Nutrient Limitation}

Although it was first reported in the literature over 100 years ago, inorganic polyphosphate (polyP) remains one of nature's most enigmatic molecules (see reference 191 for a review). The importance of polyP appears to be primal and universal, as it occurs in bacteria, archaea, plants, and animal cells $(39,134,135,170,216,273,274)$. PolyP is a polymer of orthophosphates that can be tens to hundreds of residues long, each residue linked by a highenergy phosphoanhydride bond. It is synthesized by a highly-conserved enzyme, polyphosphate kinase (Ppk, encoded by the ppk gene in E. coli) that transfers the gamma phosphate from ATP to the growing polyP polymer. In some cells, such as Saccharomyces cerevisiae, polyP serves primarily as a storage molecule, but the levels of polyP in $E$. coli and its relatives are far too low (100 uM in E. coli versus $120 \mathrm{mM}$ in $S$ cerevisiae, although levels vary widely depending on nutritional status) to provide a source of energy (131). Rather, polyP, which accumulates under various conditions of nutritional stress, appears to be an indicator of the nutritional state of the cell.

In E. coli, polyP accumulates when cells are starved for amino acids, nitrogen, or subjected to sudden osmotic stress. During amino acid starvation exopolyphosphatase (Ppx), the enzyme that degrades polyP, is inhibited by the molecular alarmones guanosine tetra- and 
penta-phosphate (ppGpp and pppGpp) (138) (ppGpp and pppGpp are discussed below and in Eco-Sal III Module 5.3.5 "Amino Acids and the Stringent Response"). The molecular pathways leading to polyP accumulation during other stresses are not as well studied. Levels of polyP also transiently spike when $E$. coli is shifted from rich to minimal medium and as cells growing in rich medium enter stationary phase (131). If, however, $E$. coli is grown with phosphate concentrations in excess of $30 \mathrm{mM}$ (as in most minimal media), levels of polyP stay elevated for at least 72 hours in stationary phase (220). PolyP is required for proper expression of rpoS in stationary phase cells (225). How this regulatory role is exerted is not understood; however, polyP can bind to RNA polymerase and direct transcription to specific promoters (139). As discussed above, RpoS levels also respond to a variety of nutritional stresses, such as amino acid deficiencies and nitrogen limitation. Thus polyP may channel the RpoS-regulated pathways for mutagenesis to more specific stress conditions.

Poly P levels may regulate SOS genes independently of DNA damage or of the RecA-LexA regulon. Overexpression of $\mathrm{Ppx}$ in E. coli, which reduces polyP levels, increased sensitivity to DNA damage and blocked the induction of $r e c A$ and $u m u D C$ by DNA damaging agents (255). Conversely, overexpression of Ppk, which results in elevated polyP levels, induced $r e c A$ gene expression, and this induction was independent of DNA damage and RecA (255). Thus polyP may induce the SOS functions, including SOS-dependent mutagenesis, in response to stresses other than DNA damage.

PolyP also has a direct role in regulating mutagenesis (238). Three widely-used assays for measuring Pol IV activity in vivo are: stationary phase adaptive mutation (see below), growth-dependent mutagenesis when Pol IV is overexpressed (123, 238, 262), and resistance to a few DNA damaging agents (148), particularly 4-nitroquinoline-1-oxide (118). In a ppk mutant $E$. coli strain, all three of these Pol IV-dependent activities are decreased but the amount of Pol IV is not affected, indicating that polyP (or possibly Ppk itself) regulates the activity of Pol IV (238). This regulation is independent of both RecA and RpoS, so the regulatory pathways described above are not involved. Pol V-dependent mutagenesis following exposure to UV light is also reduced in $p p k$ mutants (238), but in this case a negative effect on the expression of RecA, an essential cofactor for Pol V activity, has not been ruled out.

Other known activities of polyP may provide insight into its role in these Pol IV- and Pol Vdependent phenotypes. polyP regulates the proteolytic activity of Lon, an important ATPdependent protease $(137,177)$. Lon binds to DNA (47), which regulates its proteolytic activity, perhaps by sequestering it away from its substrates (231). PolyP competes with DNA for Lon's DNA-binding site, stimulating Lon's proteolytic activity; thus when polyP levels increase during nutrient limitation, it stimulates Lon to degrade proteins for nutrients (137). Similarly, polyP could modulate the activities of DNA polymerases by competing with them for DNA binding. By differentially affecting the activities of high fidelity and low fidelity polymerases, poly $\mathrm{P}$ could regulate mutagenesis. In support of this hypothesis, polyP that co-purified with DNA from the fungus Colletotrichum inhibited DNA replication by Taq polymerase in vitro (199). Whatever the mechanism, the accumulation of polyP during stationary phase and under nutrient limiting conditions enhances the activities of both Pol IV and Pol V. 


\section{The Stringent Response}

The stringent response, which is induced by amino acid limitation, is covered in detail in Eco-Sal III Module 5.3.5. "Amino Acids and the Stringent Response". Briefly, when cells are starved for amino acids or phosphorous, production of the alarmone (p)ppGpp is stimulated. (p)ppGpp, in association with the accessory protein DksA, binds to RNA polymerase (RNAP), blocks transcription of ribosomal and transfer RNAs (stable RNAs) and directs active RNAP to genes that help the cell to cope with nutrient limitation. One gene that is up-regulated by (p)ppGpp is rpoS (91); this regulation is complex, involving both direct and indirect pathways $(28,38,141,143)$. In addition, many RpoS-regulated genes also require (p)ppGpp for efficient expression (141). Thus, the stringent response, mediated by (p)ppGpp, is intimately intertwined with the general stress response controlled by RpoS, linking the mutagenic processes regulated by RpoS (described above) to the additional stress factors that regulate (p)ppGpp. Microarray analysis has shown that several genes of the SOS regulon are also induced during the stringent response, suggesting that LexA is inactivated (65). Thus the mutagenic potential associated with SOS functions may also be upregulated during amino acid starvation.

In E. coli and B. subtilis (p)ppGpp acts as a replication checkpoint, linking DNA replication to the availability of nutrients that support growth and cell division (97). In E. coli, (p)ppGpp inhibits replication initiation (219), whereas in B. subtilis it inhibits replication elongation $(8,258)$. At least in the case of $B$. subtilis, the integrity of the replication fork is not affected and DNA repair proteins are not recruited. Since error-prone DNA polymerases may participate in replication restart (114), (p)ppGpp-induced replication restart may increase the potential for mutations.

Another link between (p)ppGpp and mutagenesis occurs at the level of transcription. Actively transcribed genes have been shown to have increased spontaneous mutation rates in E. coli (15, 16, 125, 126, 266), B. subtilis (212), Saccharomyces cerevisiae (57), and mammalian stem cells (111). Thus transcription-coupled mutagenesis is, at least to some extent, a general phenomenon. Indeed, it has been argued that transcription "directs" mutations to genes whose products are most relevant under adverse conditions $(58,71,194$, 265), and that the selective transcriptional activation of genes is a driving force of evolution (265). In some cases transcription-dependent increases in mutation rates require active RelA (which synthesizes (p)ppGpp), and thus are linked to the stringent response $(194,212)$. Actively transcribed genes may have higher mutation rates because transcription produces a bubble of single-stranded DNA, and single-stranded DNA is intrinsically more susceptible to DNA damage than is double-stranded DNA (149). In support, recent results suggest that the nontranscribed DNA strand, which forms a loop during transcription, is more susceptible to mutagenesis than the transcribed strand, which is hybridized to RNA (125). To cope with the effect of DNA damage on transcription, E. coli and other organisms have evolved a mechanism, called transcription-coupled repair (TCR), that recruits DNA repair enzymes, particularly the proteins of the nucleotide excision repair (NER) pathway, to stalled transcription complexes (for more details see reference 165 and Eco-Sal III Module 7.2.4. "DNA Damage Reversal and Excision Repair"). Mfd, the transcription coupling factor in bacteria, is required for stationary-phase mutation in B. subtilis, suggesting that the recruited 
repair synthesis is responsible for mutations (205). However, Mfd was found not to be necessary for at least one stress-induced mutational pathway in E. coli (33), and loss of Mfd even has a mild mutator phenotype for some mutational targets (125).

A role for transcription in stress-induced mutagenesis is not universal. Adaptive mutation to $\mathrm{Lac}^{+}$during stationary phase was not increased by inducing transcription of the lac operon with the gratuitous inducer IPTG (80). In another study, reversion to $\mathrm{Trp}^{+}$in E. coli increased during tryptophan deprivation even in the absence of transcription of the target gene (12). Error-prone DNA synthesis has been linked to transcription in a pathway called transcription-coupled translesion synthesis (51). An interaction between the RNAPassociated protein NusA and DNA Pol IV has been proposed to recruit the polymerase when RNAP is blocked by a gap in the transcribed strand opposite a replication-blocking lesion in the non-transcribed strand. One of the translesion polymerases, DNA Pol II, IV or V could then fill in the gap, allowing transcription to continue. Because of the error-prone activity of Pol IV or Pol V, this process could be mutagenic (52).

\section{The heat- and cold-shock responses}

Because bacteria have no mechanism for internal temperature homeostasis, they rely on global responses to temperature shifts called the heat-shock and cold-shock responses. The heat shock response is mainly regulated by the alternative sigma factor $\mathrm{RpoH}\left(\sigma^{32}\right.$ or $\left.\sigma^{\mathrm{H}}\right)$, although the extracytoplasmic stress sigma factor, $\operatorname{RpoE}\left(\sigma^{24}\right.$ or $\left.\sigma^{\mathrm{E}}\right)$, can also respond to extreme temperature shifts (see references 100, 201, 271, and Eco-Sal III Module 5.4.7 "Envelope Stress Responses"). The RpoH regulon is also induced by carbon source or amino acid starvation, heavy metal exposure, antibiotics, DNA damage, oxidative stress, and bacteriophage infection.

One of the proteins induced as part of the heat shock response is the highly conserved GroE chaperone (the E. coli HSP60). GroE aids in the proper folding and stability of many proteins and is essential even at normal temperatures. GroE is required for the normal levels of both of E. coli's error-prone polymerases. GroE interacts with the UmuC subunit of Pol V and protects it from proteolytic degradation; thus, when levels of GroE are reduced, UV mutagenesis, which is a function of Pol V, is abolished $(60,61,151)$. Likewise, the amount of Pol IV is reduced by $90 \%$ in GroE deficient mutant strains. GroE probably directly interacts with Pol IV; the large subunit of GroE (GroEL) was recovered from E. coli whole cell lysates passed over a DinB column (94), and both the large and small subunits copurified with affinity purified DinB (226). That Pol IV and Pol V levels are stabilized by GroE suggests that the error-prone polymerases may have important functions during exposure to high temperature or other stress conditions that induce the RpoH regulon. In addition, when levels of GroE are low, stationary phase adaptive mutation is reduced even in the absence of Pol IV, suggesting that GroE has some additional mutagenic function (146).

A connection between cold shock and mutagenesis is suggested by the temperaturedependent regulation of the $E$. coli small histone-like protein, $\mathrm{HU}$, and the transcription factor NusA. (for more information about cold shock see Eco-Sal III Module 5.4.2 "The Cold Shock Response"). In E. coli, HU has two homologous subunits, HUa and HU $\beta$ (encoded by the paralogous genes hupA and $h u p B$ ), and exists in three dimeric forms: $\mathrm{HUa}_{2}$, 
$\mathrm{HU} \beta_{2}$, and $\mathrm{HUa} \beta$ (211). The relative levels of these forms vary during the cell cycle and under certain stress conditions (50). $\mathrm{HUa}_{2}$ and $\mathrm{HUa}$ and $\beta$ have higher affinities for most of their substrates than does $\mathrm{HU} \beta_{2}$ (184) and are usually the most abundant of the three forms (50). However, the expression of $h u p B$ but not of $h u p A$ increases after exposure to low temperatures, thus increasing the relative amounts of $\mathrm{HUa} \beta$ and $\mathrm{HU} \beta_{2}$ (92). Cold-shock also results in increased levels of NusA; indeed NusA is one of the most highly induced proteins after temperature downshift (249). Both the HUßB heterodimer (260) and NusA (52) are required for maximum stationary phase adaptive mutation in $E$. coli (see below). Although the pathways may be different, increased levels of these two factors at low temperatures may facilitate mutagenesis and may account for the observed temperature dependence of adaptive mutation $(52,79)$.

\section{Other Factors That Affect Mutagenesis}

\section{Antibiotics that induce the SOS response}

In E. coli and other bacteria, antibiotic treatment can induce the SOS response, resulting in increased mutagenesis that may facilitate the development of resistance $(49,159,167,230)$. Quinolone antibiotics target two essential enzymes involved in DNA replication: DNA gyrase, a type II topoisomerase that releases positive supercoils ahead of the replication fork; and topoisomerase IV, another type II topoisomerase that decatanates intertwined daughter chromosomes (as well as releasing negative supercoils $(64,272)$. The quinolone antibiotics inhibit topoisomerase activity after DNA cleavage but before the DNA is rejoined, resulting in double strand breaks that induce the SOS response $(64,122)$. Resistance to quinolone antibiotics is conveyed by point mutations in the chromosomal genes encoding DNA gyrase and topoisomerase IV, and SOS induction increases the probability of these mutations. In a mouse model system, the quinolone antibiotic ciprofloxacin accelerated the development of resistance of pathogenic E. coli (48). In reconstruction experiments the mutations required for ciprofloxacin resistance were dependent on RecA, RecBCD, and the SOS-induced DNA polymerases Pol II, Pol IV, and Pol V (48), genetic requirements similar to adaptive mutation. Also like adaptive mutation, resistant mutants appeared steadily over the course of two weeks when $E$. coli cells were incubated on medium containing sub-lethal concentrations of ciprofloxacin. In a similar study of infection by Mycobacterium tuberculosis, deletion of the SOS-regulated polymerase DnaE2 reduced both the virulence of the bacteria and the frequency at which mutations conferring rifampicin resistance arose (26). One possible explanation is that the polymerase simply increases fitness of the bacteria in the mouse; a more stimulating hypothesis is that mutations caused by DnaE2-dependent DNA synthesis enhance adaptation to the host immune response as well as development of antibiotic resistance (26).

Antibiotics can also induce the SOS response independently of DNA damage (167). The sulA (also known as sfiA) gene is one of the most highly up-regulated genes of the SOS regulon $(54,188)$ and is a potent inhibitor of cell division. $\beta$-lactam antibiotics bind to and inactivate penicillin binding proteins (PBPs), a class of proteins involved in cell wall biosynthesis (157). This binding induces the SOS response via the DpiBA two-component signal transduction system; expression of SulA inhibits cell division, rendering the cells 
temporarily resistant to the antibiotic (167). At the same time, SOS induction of Pol V and Pol IV would lead to an increased mutation rate and a higher probability of mutations rendering the cell resistant to the antibiotic. In particular, Pol IV-dependent mutations are induced by exposure to $\beta$-lactam antibiotics, and the induction of the $\operatorname{din} B$ gene after exposure to $\beta$-lactam antibiotics is partially independent of RecA/LexA control (182).

Interference with the mechanisms by which the SOS response is induced by antibiotics is a potential target for new classes of antimicrobial agents (230). Likewise, proteins for recombination and DNA repair are potential targets. Because these proteins are conserved $(67,239)$, such therapeutic agents may have broad antimicrobial applications.

\section{Translation errors caused by antibiotics}

In bacteriostatic concentrations, aminoglycoside antibiotics that inhibit translation, such as streptomycin, cause a SOS-independent mutator state known as "translational stress-induced mutagenesis" $(11,195)$. These antibiotics can affect the fidelity of amino acid incorporation into growing polypeptides $(10,206)$ potentially altering the activities of proteins involved in DNA replication and repair. Such mistakes during translation were predicted to produce a transient mutator state (176). For example, cells carrying a mutation in the glyV tRNA gene ( mutators because they express a mutant proofreader subunit of DNA Pol III $(5,6,228,229)$.

\section{Plasmid addiction modules}

To ensure their maintenance and propagation in a population, low-copy plasmids, including conjugal plasmids such $\mathrm{F}$, commonly encode plasmid addiction or post-segregational killing systems. The F plasmid carries the Ccd system encoded by the $c c d A$ and $c c d B$ genes (112). $\mathrm{CcdB}$ is a potent inhibitor of DNA gyrase and induces the SOS regulon by the same mechanism as do quinolone antibiotics $(18,19,55)$. Because the antitoxin CcdA is also being produced, $\mathrm{CcdB}$ is not active in cells carrying $\mathrm{F}$ under most circumstances. However, a recent study showed that the levels of both $\mathrm{CcdA}$ and $\mathrm{CcdB}$ increase when cells enter stationary phase (4). The stoichiometry of $\mathrm{CcdA}$ and $\mathrm{CcdB}$ under various conditions is not known, but if the amount of CcdB exceeds CcdA, SOS induction could occur. Thus, Fencoded functions could gratuitously activate the SOS response, increasing mutation rates without any exogenous DNA damage. As proof of this principle, overexpression of CcdB from a plasmid resulted in a modest increase in adaptive reversion to $\mathrm{Lac}^{+}$of an $\mathrm{F}^{\prime}$ encoded lac allele (4).

\section{Specific Systems for the Study of Stress-Induced Mutagenesis}

As described above, states of transient genetic instability can be induced by a number of environmental factors. In most of these cases, the stimuli are linked to the resulting genetic instability via complex pathways; thus, these mutator states do not provide tractable systems for the study of stress-induced mutation. However, several genetic systems have been developed that allow the investigation of changes in mutation rates in response to welldefined conditions. The examples presented below are not exhaustive and other systems exist for $E$. coli and other organisms (113, 116, 119, 130, 217, 246, 248); however, these 
examples are representative of the types of model systems used to study stress-induced mutagenesis.

\section{Mutagenesis due to spontaneous DNA damage}

As a bacterial population exhausts its resources, metabolic and local environmental conditions can result in spontaneous DNA damage. As discussed above, such damage can result in induction of the SOS response and a general increase in mutation rates. In other cases, specific pre-mutagenic lesions can cause mutations independently of SOS functions. A number of experimental systems have been devised to provide insight into these pathways.

Oxidative damage appears to be a significant factor leading to DNA damage and mutation in both growing cells $(20,169,215)$ and in nutritionally deprived cells $(17,21,31,34-36,66)$. Reactive oxygen species are the normal products of metabolism in aerobic environments, but unless controlled, reactive oxygen species are destructive to many cellular components, including DNA. One particularly mutagenic consequence of oxidative damage is the formation of 7,8-dihydro-8-oxo-2'-deoxyguanine (8-oxoG), which causes predominantly G:C to T:A transversion mutations (166). Using an experimental system that discriminates between mutations occurring in dividing and non-dividing cells, Bharatan and colleagues (2004) found that MutY (a glycosylase that removes adenines paired with 8-oxoG) (166), MutT (an 8-oxoGTP hydrolase) (166), and glycosylases that remove oxidized pyrimidines, prevented mutations in stationary phase cells (21), supporting the importance of oxidative damage in nutritionally deprived cells.

Various mutant alleles of the trp genes (encoding tryptophan biosynthetic enzymes) revert to $\mathrm{Trp}^{+}$only by specific mutational events $(268,269)$, and thus can be used to study how conditions influence these events. E. coli strains carrying some of these mutant trp alleles continuously revert to $\operatorname{Trp}^{+}$during about ten days of incubation on minimal medium lacking tryptophan. In one study, reversion to Trp ${ }^{+}$occurred via A:T to T:A and A:T to C:G transversions, required SOS functions and Pol V, and was enhanced by the plasmid-encoded MucAB homolog of Pol V (20). In contrast, in a separate study of a mut $Y$ mutant strain, most $\mathrm{Trp}^{+}$revertants were due to Pol V-dependent G:C to C:G mutations, although some SOS- and Pol V- independent reversion was also detected (250). Because the mut $Y$ defect resulted in a large increase in stationary-phase mutations (35), the authors concluded that 8oxoG, the substate of MutY, is an important pre-mutagenic lesion in nutritionally starved cells, but that damage leading to A:T transversions also must occur. However, why the loss of MutY would result in G:C to C:G mutations instead of the expected G:C to T:A mutations is unclear, although the authors suggest that MutY can act on 8-oxoG incorrectly paired with G, resulting in the G:C to C:G mutations in the next round of replication (250).

Starved cells are also subject to mutagenic alkylation damage (221). A likely source of such damage is endogenous alkylating agents formed by nitrosation of amides and related compounds (247). Most cells, including E. coli, have several enzymatic activities to repair this type of damage. The Ada and Ogt proteins remove alkyl groups from the $\mathrm{O}^{6}$ position of guanine and the $\mathrm{O}^{4}$ position of thymine (222). In strains lacking one or both of these proteins, the rate of spontaneous mutation in non-growing cells measured at several 
mutational targets was notably increased $(21,80,158,192)$. Whereas Ogt is constitutively expressed in E. coli, Ada is induced in response to alkylation damage and in stationaryphase cells under RpoS control (247). DNA Pol IV, which is also regulated in stationaryphase cells by RpoS (145), is involved in tolerance of alkylation damage, presumably because it can bypass alkylated bases in the DNA (23). The existence of multiple mechanisms to minimize the deleterious effects of alkylation damage in non-growing cells suggests that this type damage is a particularly potent mutagenic force. The regulation of both Ada and Pol IV in stationary-phase cells by RpoS further suggests that cells have evolved a coordinated system for combating alkylation damage during nutritional limitation.

\section{Mutagenesis on solid surfaces I: Resting organisms in a structured environment (ROSE)}

By placing a reporter gene (the gal operon) under control of the $\lambda$ phage genetic switch (inactivation of the CI repressor), Taddei and colleagues showed that the SOS response is induced in aging colonies without the need for any exogenous stimulus (244). SOS induction under these conditions required RecA and RecB, implying that RecBCD processing of double strand ends was required to produce the SOS initiating signal. While RpoS was dispensable, adenylate cyclase, the enzyme responsible for cAMP production, was required. Since intracellular concentrations of cAMP increase dramatically in nutritionally limited cells (40), these results suggest that SOS was being induced by DNA double-strand breaks occurring as consequence of starvation. Taddei and colleagues found a 9-fold increase in the frequency of rifampicin resistant $\left(\mathrm{Rif}^{\mathrm{R}}\right)$ mutants in seven-day old colonies relative to one-day old colonies, suggesting that SOS induction leads to increased mutagenesis in starving cells. Interestingly, while a similar induction of the SOS response occurred in liquid cultures, no change in mutation frequency was detected. Thus the special conditions pertaining to growth in a colony on a solid substrate appeared to be required for this mutagenic effect (243). This mutational phenomenon was called ROSE mutagenesis, for "resting organisms in a structured environment." In subsequent studies ROSE mutagenesis was shown to require $u v r B$ (a component of nucleotide excision repair), and DNA polymerase I (Pol I), but not Pol V (Pol IV was not tested), suggesting that the mutations arise during nucleotide excision repair (243).

Why growth in a colony is required for this type of starvation-induced mutagenesis is not obvious. As discussed above, other studies have shown that inactivation of the enzymes that repair oxidative DNA damage results in significant increases in mutation rates in cells aging on solid media $(17,21,31,34,36,158,192)$. That ROSE requires SOS functions, nucleotide excision repair, double-strand break repair, and Pol I, suggest that cells in colonies experience DNA damage by agents unique to this growth condition.

\section{Mutagenesis on solid surfaces II: Mutagenesis in aging colonies}

Most studies of stress-induced mutagenesis have used laboratory strains of $E$. coli, thus it is possible that genetic changes accompanying domestication have influenced the observed mutagenic processes. To address this issue Bjedov and colleagues (24) collected 787 natural isolates of commensal and pathogenic E. coli over a wide geographical range and from diverse environmental niches. They compared the frequency of Rif ${ }^{\mathrm{R}}$ mutant cells in one- and seven-day old colonies and called the ratio MAC, for "mutagenesis in aging colonies". 
Among all the isolates the average increase in the frequency of Rif ${ }^{\mathrm{R}}$ mutant cells was sevenfold, slightly higher than that of the laboratory strain, MG1655. Over the same period there was, on average, less than a twofold increase in the number of cells in the colonies. About $3 \%$ of the isolates were constitutive mutators (high Rif ${ }^{\mathrm{R}}$ frequency on day one). Among the other isolates, the ratio of day seven to day one frequencies ranged widely (up to 100-fold). Pathogenic strains were more frequently constitutive mutators, whereas commensal strains typically had higher MAC. Interestingly, there was a negative correlation between the MAC phenotype and the constitutive mutator phenotype, suggesting that the two are mutually exclusive. Using ten randomly chosen isolates, Bjedov (24) further showed that MAC required carbon-source starvation on solid medium (like ROSE, see above) and aerobic conditions. In one strain with a particularly strong MAC phenotype, MAC was found to require RpoS, cyclic-AMP, the cAMP receptor protein (CAP), and RecA, but not LexA inactivation. The latter result suggests a requirement for recombination but not for other SOS functions. MAC was reduced by overproduction of MutS, suggesting that a decline in mismatch repair contributes to the mutagenesis. While MAC and ROSE share a number of features, they differ in that MAC requires DNA Pol II, rather than Pol I, and does not require nucleotide excision repair.

A subsequent report argued that the MAC phenotype is not due to increased mutation rates in aging cells, but is, instead, a consequence of growth advantages conferred by mutations in the $r p o B$ gene that that confer Rif ${ }^{\mathrm{R}}$ (264). In support of this hypothesis, Wrande and colleagues (264) demonstrated that $\mathrm{Rif}^{\mathrm{R}}$ mutants were localized in defined regions of colonies and $\mathrm{Rif}^{\mathrm{R}}$ cells from the same region had the same mutations, suggesting that clones of Rif ${ }^{\mathrm{R}}$ cells grew from an early arising mutant. Also, the increase of Rif ${ }^{\mathrm{R}}$ mutant frequency measured over 28 days could be fit to a logarithmic curve, suggesting that the Rif ${ }^{\mathrm{R}}$ mutants were growing, not appearing as a result of independent mutational events. Finally, reconstruction experiments showed that certain Rif $^{\mathrm{R}}$ mutants did, in fact, have an apparent growth advantage in aging colonies. While these data appear to be compelling, they are not conclusive since they do not address a number of points in the original study. In reconstruction experiments with a number of different $r p o B$ mutants, Bjedov and colleagues (24) showed that the number of added $\mathrm{Rif}^{\mathrm{R}}$ cells in aging colonies remained constant or slightly declined. When constitutive mutator strains (such as mutS or mutT mutants) were incubated for seven days, their initial high frequencies of $\mathrm{Rif}^{\mathrm{R}}$ mutants did not further increase, as would be expected if Rif ${ }^{R}$ mutants were selectively advantaged. Finally, among isolates there was a positive correlation between mutation to $\mathrm{LacI}^{-}$and mutation to $\mathrm{Rif}^{\mathrm{R}}$ (24), implying that mutagenesis in aging colonies is not restricted to the $r p o B$ gene. If the MAC phenomenon is ultimately substantiated, then it is the most general example to date of stress-induced genetic variability.

\section{Adaptive mutation in E. coli strain FC40}

Adaptive mutation has been most widely studied using the Foster-Cairns system for detecting stress-induced mutations, which relies on a Lac ${ }^{-}$strain of E. coli called FC40. When FC40 is incubated with lactose as the sole carbon and energy source, revertants to $\mathrm{Lac}^{+}$appear over the course of several days (Fig. 1) (43). The $\mathrm{Lac}^{+}$mutations arise in the static population and have unique genetic requirements, suggesting novel mechanisms 
specific to nutriotionally starved cells. This phenomenon, now called adaptive mutation (43), was originally called "directed mutation" because it was interpreted to be a mechanism by which mutations could be directed to the specific genes that would relieve the selective pressure. While this interpretation was not substantiated by subsequent experimentation, adaptive mutation remains an intriguing phenomenon. Despite extensive data, a consensus has not yet been reached regarding the mechanism and significance of adaptive mutation. Here we summarize the data and discuss the controversies and implications of the alternative models.

\section{Genetic properties of strain FC40 (see Fig. 2)}

The most studied case of adaptive mutation occurs in E. coli strain FC40 (43). Adaptive $\mathrm{Lac}^{+}$reversion in FC40 depends on a number genetic features specific to the strain, and these present an ideal dove-tailing of genetic elements on the chromosome and the $\mathrm{F}^{\prime} 128$ episome that it carries. FC40 is a rifampicin-resistant descendent of the strain P90C, which is also known as CSH142 (168). P90C has a deletion of approximately 2.5 minutes of its chromosome including the lac and proAB operons. While $\operatorname{din} B$ (the gene encoding DNA Pol IV) is linked to this region, it is not deleted $(124,236)$. The deletion, originally known as $\Delta(\text { lac-pro })_{\mathrm{XIII}}$ but now known as $\Delta$ (gptlac)5, is complemented by the $\mathrm{F}^{\prime} 128$ episome, which carries almost three minutes of the E. coli chromosome, including the lac region, proAB, and $\operatorname{din} B$ (129). The lac allele on the episome carried by FC40థ(lacI33-lacZ), has three mutations: the $\operatorname{lacl}^{\mathrm{q}}$ mutation that increases transcription from the lacI promoter (218); a deletion that fuses lacI to lacZ, removing the entire lac operon regulatory region and putting the operon under control of the constitutive lacI ${ }^{\mathrm{q}}$ promoter $(29,173)$; and, a +1 frameshift mutation in lacI, lacI33, changing a run of three G:C basepairs to four (46). The lacI33 mutation is polar on lacY, making FC40 defective for the lactose permease. Because of the way that $\mathrm{F}^{\prime} 128$ was formed, $\operatorname{din} B$ is closer to lac on the episome than it is in its normal position on the chromosome (129). While FC40 is phenotypically $\mathrm{Lac}^{-}$, some residual $\beta$ galactosidase activity (about 2 Miller units) is present, probably as a consequence of ribosomal frameshifting. Because the $l a c I^{q}$ promoter is weaker than the lac promoter, a true $\mathrm{Lac}^{+}$revertant of FC40 makes about 200 Miller units of $\beta$-galactosidase instead of the 1000 Miller units produced by fully induced wild-type strains. Because of this low level of $\beta$ galactosidase activity, $\mathrm{Lac}^{+}$revertants of $\mathrm{FC} 40$ take two days to produce $\mathrm{Lac}^{+}$colonies on lactose $(43,77)$.

\section{Measurement of adaptive mutation}

Measurement of adaptive mutation requires that lactose be the only carbon source available for metabolism by FC40. When incubated in liquid minimal lactose medium, the number of Lac $^{-}$cells is constant for several days (77); however, when FC40 is plated on solid minimal lactose medium the cells can double several times in the first few days after plating due to impurities in the agar (43). To limit this growth, FC40 is plated with an excess of $\mathrm{Lac}^{-}$ "scavenger cells" that can neither revert to $\mathrm{Lac}^{+}$nor recombine with FC40 to produce $\mathrm{Lac}^{+}$ recombinants (43). For a typical adaptive mutation experiment, FC40 cells are grown to saturation in minimal glycerol medium, mixed with a 10-fold excess of scavenger cells, and plated on minimal lactose plates. The plates are incubated for five days and the newly arising colonies are scored each day after the second day. During this period, $\mathrm{Lac}^{+}$colonies 
appear at a constant rate, but after five days the rate typically accelerates. This acceleration is due to: (1) growth of Lac cells on nutrients excreted by early arising colonies (crossfeeding), and possibly, on the products of lactose breakdown; and (2) an increasing number phenotypically $\mathrm{Lac}^{+}$colonies that are due to amplification of the lac region (see below).

\section{Phenomenology of adaptive mutation}

The extensive study of $\mathrm{Lac}^{+}$adaptive mutation in $\mathrm{FC} 40$ has produced the following observations:

1. During growth under non-selective conditions, the reversion rate to $\mathrm{Lac}^{+}$is about one per $10^{9}$ cells per generation. When cells are under lactose selection, the mutation rate is $20-50 \mathrm{Lac}^{+}$revertants per $10^{8}$ cells per day $(43,77)$.

2. With lactose as the only carbon source, adaptive mutations to $\mathrm{Lac}^{+}$occur in liquid cultures at about the same rate as on solid plates (77). Thus, in contrast to the MAC phenotype described above, $\mathrm{Lac}^{+}$reversion does not require a structured environment (although in liquid medium, cells can settle to the bottom of the culture vessel.)

3. $\mathrm{Lac}^{+}$reversion does not occur when FC40 is incubated in the absence of any carbon source. However, upon addition of lactose, the reversion rate to $\mathrm{Lac}^{+}$ follows the normal kinetics $(43,77)$. Thus, starvation alone is not sufficient for adaptive mutation. Because the lac allele is somewhat leaky, it appears that some energy is required for adaptive mutations to occur, most likely to allow a small amount of DNA synthesis (see below).

4. The reversion rate to $\mathrm{Lac}^{+}$is constant for about five days; during this time the number of Lac $^{-}$cells on the plate is stable $(43,77)$.

5. During lactose selection $\mathrm{Lac}^{-}$cells accumulate non-selected mutations, disproving the hypothesis that mutations to $\mathrm{Lac}^{+}$are "directed" by the selective pressure (41, $76,77,183)$. The rate of accumulation of non-selected mutations is higher on the episome than on the chromosome $(41,76,77)$, possibly due to more frequent episomal replication and recombination.

6. The accumulation of non-selected mutations is 20- to 100- fold higher in $\mathrm{Lac}^{+}$ adaptive revertants than in the $\mathrm{Lac}^{-}$population $(200,253)$. Upon re-testing, $\mathrm{Lac}^{+}$ revertants with non-selected mutations do not have increased mutation rates, i.e. they are not genetic mutators. Thus, at least some cells exhibit a transient hypermutator phenotype while under lactose selection (discussed below).

7. The unreverted lac allele can amplify during lactose selection, producing phenotypically $\mathrm{Lac}^{+}$colonies. During the five days of a normal adaptive mutation experiment, only about $2 \%$ of the $\mathrm{Lac}^{+}$colonies consist of cells with $\mathrm{lac}^{-}$ amplifications $(77,81)$; however, after ten days of incubation on lactose plates, up to $60 \%$ of the $\mathrm{Lac}^{+}$colonies are due to cells with amplifications of the $\mathrm{lac}^{-}$allele $(108,186)$. One model of adaptive $\mathrm{Lac}^{+}$mutation postulates that amplification is a precursor to true $\mathrm{Lac}^{+}$reversion (see below). 


\section{Genetic requirements of adaptive mutation}

Extensive genetic analysis has led to a significant, although not complete, understanding of the mechanism of $\mathrm{Lac}^{+}$adaptive mutation in strain FC40. The genetic requirements described here and summarized in Table 2 demonstrate that adaptive mutation is a distinct and genetically independent process from growth-dependent mutation.

1. Types of mutations-One of the most important features that differentiates adaptive mutation from growth-dependent mutation is the type of mutation that occurs. Because the activity of the lacI region of the lacI-lacZ fusion protein is irrelevant, any mutation that restores the reading frame within a 130 base-pair target will revert the $\Phi$ (lacI33-lacZ) allele. In growing cells, mutation to $\mathrm{Lac}^{+}$can occur by a number of events that restore the reading frame, most commonly duplications, deletions, and large frameshifts $(83,204)$. In contrast, adaptive $\mathrm{Lac}^{+}$mutations are almost exclusively -1 base pair frameshifts in runs of $\mathrm{G}: \mathrm{C}$ base pairs. Runs of iterated base pairs are hotspots for frameshift mutations because during DNA replication, the $3^{\prime}$ terminus of the growing strand can slip backwards forming a normal base pair with another complementary base in the iterated sequence (237). Frameshifts are normally repaired by MMR in E. coli, which led to the hypothesis that the shift in the spectrum of mutations during adaptive mutation was due to a decline in MMR (83, 154, 204). And, indeed, two MMR proteins do decline in nutritionally deprived cells (105, 254). However, the MMR activity that remains is sufficient to correct $99 \%$ of the errors that produce $\mathrm{Lac}^{+}$adaptive mutations (75). A better-supported hypothesis it that the mutational shift is due to increased activity of DNA Pol IV (see below).

2. Dependence on the $\mathbf{F}^{\prime}$ episome-Maximum adaptive mutation in FC40 requires that the lac allele is carried on the episome. When the same allele is in its normal position on the chromosome, the rate of adaptive mutation falls 100 -fold $(84,189)$ and this low rate of reversion does not require the recombination functions that are required for adaptive mutation on the episome $(84,90)$. The maximal level of adaptive mutation on the episome also requires the expression of the $\mathrm{F}$ conjugal functions (the tra operon); however, actual conjugation is not required (84). In the absence of conjugal functions, adaptive mutation falls 10-fold, but recombination functions are still required (84). Several models of adaptive mutation predict that the required conjugal factor is TraI, the enzyme that nicks the conjugal origin to initiate conjugal DNA replication $(84,90,140,185,198,202)$. However, selective inactivation of several tra genes, including traI, induce the same 10-fold reduction in adaptive mutation $(84,90)$. This is probably because conjugation requires a large multiprotein complex and inactivation of any one gene may disrupt the entire machine (144).

3.Dependence on DNA polymerases-Loss of DNA Pol IV reduces adaptive mutation $50 \%$ to $80 \%(72,163)$. E. coli's other error-prone DNA polymerase, Pol V, makes little or no contribution $(43,162)$, probably because Pol V does not readily produce the frameshifts that revert the Lac' allele in FC40. The role of E. coli's third inducible DNA polymerase, Pol II ( $p o l B)$, is not so simple. Pol II is active under the conditions used to measure adaptive mutation, but, because of its high fidelity, it produces few $\mathrm{Lac}^{+}$mutants unless its proofreading function is inactivated $(68,81)$. The residual Pol IV-independent $\mathrm{Lac}^{+}$adaptive mutations seen in a $\operatorname{din} B$ mutant strain are reduced about 20 to $50 \%$ if Pol II is also missing 
$(72,109)$. However, if only Pol II is missing, the rate of adaptive mutation increases about 3 -fold and all of these extra mutations are due to Pol IV $(68,72,109)$. Thus, Pol II limits the mutagenic potential of Pol IV during lactose selection, possibly by competing with it for substrates or other shared factors (such as access to the $\beta$ sliding clamp). In addition, polB mutant cells overproduce Pol IV, most likely because loss of Pol II results in partial induction of the SOS response (145) (although this interpretation is disputed; see reference 109). Interesting, whether or not the other polymerases are present, $\mathrm{Lac}^{+}$adaptive mutations are reduced by the presence of the dnaE915 allele, which encodes an antimutator version of the polymerase subunit of Pol III. This result suggests that the DnaE915-containing Pol III is an antimutator because it limits the access of less accurate polymerases to the DNA (72, 109).

As mentioned above, FC40 and other P90C-derived strains carrying the $\mathrm{F}^{\prime} 128$ episome have copies of $\operatorname{din} B$ on the chromosome and on the episome. For unknown reasons, expression of $\operatorname{din} B$, as well as other genes, is higher on the episome, so that the amount of Pol IV in such F ' cells can be as much as 4-fold greater that in $\mathrm{F}^{-}$cells (124). This is clearly a factor contributing to FC40's high rate of adaptive mutation (see below).

4.Influence of specific stress responses-As summarized in Table 1, five separate global stress responses impact the levels or activities of Pol IV and, consequently, also impact adaptive mutation. However, with the possible exception of the SOS response (89), it is unlikely that an effect on Pol IV is the only way these stress responses affect adaptive mutation. As discussed above, both loss of the general stress response sigma factor, RpoS $(145,153)$, and reduction in the levels of heat shock chaperone GroE (146), reduce adaptive $\mathrm{Lac}^{+}$reversion about 10-fold. Much of this decrease is due to reduced levels of Pol IV, but in each case there is an additional Pol IV-independent effect (145, 146, 153). Interestingly, the Pol IV-independent effect of GroE is only seen a $\operatorname{rec} G$ mutant strain (146). Likewise, Ppk, the enzyme that makes polyP, is required for maximal Pol IV activity, but Ppk also makes a small Pol IV-independent contribution to adaptive mutation (238). Thus, these stress responses have more complex roles in adaptive mutation than simple Pol IV regulation.

\section{DNA repair and recombination functions}

Recombination functions: The genes and their products that have been demonstrated to influence adaptive mutation are listed in Table 2. Adaptive mutation in FC40 depends on DNA repair and recombination pathways, indicating that, although not dividing, starved cells are not inert for DNA metabolism. In the absence of the RecA recombinase and the RecBCD end-processing complex, adaptive mutation in FC40 is nearly eliminated $(43,106)$. Thus, adaptive mutation requires the recombination pathway that repairs DNA double strand breaks. In addition, the RuvABC Holliday junction-processing machine is required (86, 107). In the absence of the RecG, a Holliday junction-processing helicase, adaptive mutation increases up to 100-fold $(86,107)$, and the extra mutations are due to Pol IV (145). Cells lacking RecG are partially induced for the SOS response $(152,160)$ and have 3- to 4-fold more Pol IV than wild-type cells (145). The helicase activity of RecG may also have a direct 
role in adaptive mutation, which is normally obscured by the effect of excess Pol IV in recG mutant cells (see below).

That a 3- to 4-fold increase in Pol IV could produce a 100-fold increase in mutation rate in a $r e c G$ mutant requires some explanation. One possibility is that the extra DNA polymerase errors produced by Pol IV saturate the capacity of the MMR system, and so more mismatches are uncorrected and become mutations. And, indeed, the extra $\mathrm{Lac}^{+}$mutations in a $\operatorname{rec} G$ mutant strain are relatively insensitive to loss of MMR but are extraordinarily sensitive to overproduction of MMR proteins (86). A second, nonexclusive possibility is that DNA Pol II normally may compete with and limit the mutagenic activity of Pol IV (72).

Both Pol II and Pol IV are induced as part of the SOS response, but the level of Pol IV induction, at least after UV irradiation, is about 4-fold higher than that of Pol II (54). Thus, the SOS induction in a recG mutant strain may allow Pol IV to out-compete Pol II. This last hypothesis could also apply to other factors that limit Pol IV's mutagenic activity.

Loss of the RecD subunit of RecBCD eliminates the nuclease but not the helicase activity of the complex. FC40 recD mutant strains have a 10- to 30 -fold increase in adaptive mutation (106). $r e c D$ mutant strains are hyper-recombinogenic and have greatly elevated plasmid copy numbers $(22,110,155,197,223)$. The $\mathrm{F}^{\prime}$ episome is not immune to this effect and its copy number steadily increased when the $\mathrm{rec} D$ mutant derivative of FC40 was incubated on lactose (82). The resulting higher number of copies of the leaky $\Phi$ (lacl33-lacZ) allele resulted in sufficient $\beta$-galactosidase to allow the $\mathrm{Lac}^{-}$cells to weakly grow on the lactose medium and produce increasing numbers of $\mathrm{Lac}^{+}$revertants. Because the rate of $\mathrm{Lac}^{+}$ reversion was driven by cell proliferation and increasing numbers of the lac mutational target, in this special case the appearance of new $\mathrm{Lac}^{+}$mutants increased exponentially, not linearly as observed when the cells are not dividing (82). The ability to differentiate an exponential increase from a linear increase in the numbers of $\mathrm{Lac}^{+}$mutants in these different genetic backgrounds supports the conclusion that normal $\mathrm{Lac}^{+}$adaptive reversion is, in fact, constant with time.

Mismatch repair: MMR monitors and repairs the DNA polymerase errors that lead to adaptive $\mathrm{Lac}^{+}$revertants. Adaptive mutation increases 100 -fold when MMR is inactivated, (80) or when the strand discrimination ability of MMR is thwarted by overexpressing the Dam methylase (86). Adaptive mutation decreases when MMR proteins (particularly MutS and MutL, or both in combination) are overexpressed $(75,81,105)$. However, overproduction of MMR proteins also decreases the mutation rate in growing cells, which implies that MMR capacity is limited both when cells are growing and when they are starved $(75,81)$ (although the implications of these results are disputed; see references 75 , 104). Additionally, loss of mismatch repair has no effect on the frequency of non-selected mutations in $\mathrm{Lac}^{+}$cells, suggesting that mismatch repair is inactive in hypermutating cells (200) (see below).

HU: The small histone-like protein HU is required for maximum adaptive mutation (260). $\mathrm{HU}$ is involved in a number of recombination and repair pathways and is regulated as part of several stress responses (see above and Table 2). In E. coli, HU consists of two closely related subunits: $\alpha$ and $\beta$, and exists in the cell as three forms: the two homodimers and the 
heterodimer. $\mathrm{HUa}_{2}$ is prevalent during exponential phase but $\mathrm{HUa} \beta$ becomes more prevalent in stationary phase (50). The absence of either subunit, while having little effect on survival, decreases adaptive mutation about $70 \%$, indicating that the heterodimer is required for maximum levels of adaptive mutation (260). This effect has both Pol IVdependent and Pol IV-independent components and is independent of the sigma factor, RpoS, which HU is known to regulate. However, loss of the heterodimer has no effect in a $r e c G$ mutant strain. One hypothesis to explain this result is that the heterodimer, but not either homodimer, helps to channel recombination intermediates for resolution via a RuvABC-dependent mutagenic pathway instead of a RecG-dependent non-mutagenic pathway (260).

As mentioned above, when E. coli is subjected to cold shock, expression of HU $\beta$ is upregulated and expression of HUa is blocked, resulting in increased levels of HUaß2 (92). This effect, plus the intrinsic instability of DNA Pol IV at normal temperatures and its stabilization by GroE (see above), as well as the increased levels of NusA at low temperatures (see above), may account for the observed increase in adaptive mutation at lower temperatures $(52,79)$.

NusA: Maximum levels of adaptive mutation require the activity of the transcription factor NusA (52). As mentioned above, NusA interacts with Pol IV physically, and overexpression of either Pol IV or Pol V suppresses the temperature sensitivity of a nusA mutant allele (51). These results have led to the hypothesis that NusA recruites Pol IV to rescue RNA polymerase stalled at a gap in the transcribed strand opposite a lesion on the non-transcribed strand (51). This process, called "transcription-coupled translesion synthesis", could be the source of adaptive mutations (52). However, an alternative explanation is that loss of NusA activity simply reduces the level of transcription of the genes that encode proteins required for adaptive mutation, including lac $Z$ itself (207).

\section{Models for adaptive mutation}

Two main models for Lac ${ }^{+}$adaptive mutation in FC40 have emerged. The first, recombination-dependent mutation (RDM), postulates that $\mathrm{Lac}^{+}$adaptive mutations occur in non-dividing cells (78). The second model, amplification-dependent mutation (ADM), postulates that $\mathrm{Lac}^{+}$mutations occur in a small sub-population of cells that are proliferating during incubation on lactose (210). While these models are not entirely mutually exclusive, their validities are highly disputed among researchers (see references 73, 203, 208).

\section{Recombination-dependent model (see Fig. 3 and reference 78)}

The F plasmid tra functions are required for maximum levels of adaptive mutation. Even when cells are not conjugating, the TraI nickase nicks at the episomal conjugal origin, oriT (87). According to the RDM model, this persistent nick initiates the recombination pathway leading to adaptive mutation. While the episome copy-number is stable during lactose selection (82), the low level of lactose metabolism in Lac $^{-}$cells permits the occasional firing of one of the episome's vegetative origins of replication. If the resulting replication fork encounters the persistent nick at the conjugal origin, a DNA double-strand break results that initiates recombinational double strand break repair. The RecBCD complex processes the 
double strand break to generate a $3^{\prime}$ single-strand overhang, which the RecA recombinase uses to invade the homologous duplex DNA, either on the same episome or on another copy of the episome. The $3^{\prime}$ endogenous of this invading strand serves as the primer for PriAmediated, origin-independent, replication to restart the failed replication fork (for a review, see reference 161).

The RDM postulates that $\mathrm{Lac}^{+}$mutations arise as a result of the DNA synthesis initiated during this replication restart. Pol II and Pol IV compete for the $3^{\prime}$ terminus $(72,114)$. Pol II is an accurate polymerase, so if it gains access to the $3^{\prime}$ terminus, few $\mathrm{Lac}^{+}$mutations result. But if error-prone Pol IV gains access, strand slippage followed by extension results in the $\mathrm{Lac}^{+}$frameshift mutations. A possible alternative mechanism is that Pol II, or Pol III, makes a slip and that Pol IV is recruited to extend the misaligned primer-template, a known activity of Pol IV (127). Nonselected mutations, either frameshifts or base substitutions, occur on the episome by the same mechanism. The recombination step results in a Holliday junction, which is translocated and resolved by RuvABC or RecG.

According to the RDM model, the high rate of $\mathrm{Lac}^{+}$reversion on the episome is due to its tendency to initiate replication, the frequency of double-strand breaks, and their recombinational repair. The requirement for Pol IV connects RDM to nutritional stress. Since the mutation rate is dependent on the amount of Pol IV in the cell, stress induced induction or activation of Pol IV increases the adaptive mutation rate to $\mathrm{Lac}^{+}$.

\section{Amplification-dependent model (Fig. 4 and reference 210)}

The initiating event in the ADM model is a spontaneous duplication of the lac region that occurs prior to lactose selection in about one out of every thousand cells. Because the cells with a duplication are producing twice the amount of $\beta$-galactosidase as normal, they slowly grow on the lactose. Selection then favors cells that further amplify the lac region, which is a RecA-dependent process (251). As the number of cells with amplifications increases and the extent of their amplifications expand, the number of the mutational targets increases and so does the probability of a mutation that yields a true $\mathrm{lac}^{+}$revertant. Because of its proximity to $l a c$, the $\operatorname{din} B$ gene is also amplified, leading to increased levels of Pol IV. Once a true $\mathrm{lac}^{+}$revertant is formed, the selective pressure to maintain the amplified array is relieved and it is de-amplified as the $\mathrm{Lac}^{+}$cell divides. Eventually, only true $\mathrm{Lac}^{+}$cells are detectable.

It is accepted among all researchers in the field that both true revertants, due to frameshift mutations, and pseudo-revertants, due to amplification of the Lac ${ }^{-}$allele, arise during lactose selection. What is disputed is the contribution that each makes to adaptive mutation. On one side, it is argued that amplification is a separate phenomenon that accounts for a minority of the $\mathrm{Lac}^{+}$colonies that arise on lactose, and that true $\mathrm{Lac}^{+}$mutants arise by the RDM process. On the other side, it is argued that amplification is a necessary precursor to the appearance of true $\mathrm{Lac}^{+}$revertants. Without data that are accepted by all researchers in the field supporting one model over the other, the controversy is likely to persist. The fundamental question is: does the stress of selection increase the rate of mutation, or does selection simply increase the probability of a beneficial mutation with no increase in mutation rates? 
However, there is no reason that selecton could not be acting in both capacities, or that one situation could favor one mode and another situration favor the other.

\section{Transient hypermutation}

When isolated, about $1 \%$ of true $\mathrm{Lac}^{+}$adaptive revertants of FC40 carry additional nonselected mutations. When these $\mathrm{Lac}^{+}$isolates are characterized, they do not have a general increase in mutation rate, meaning that they are not constitutive mutators. Thus, during lactose selection they must have experienced a transient period of increased mutation (200, 253). This transient period of hypermutation was predicted by Hall (102), and subsequently modeled by Ninio (176) and Cairns $(42,200)$. Transient hypermutation has been reported in other $E$. coli strains $(25,102)$ and in Salmonella (227). Some researchers use the term "hypermutation", whereas others refer to the same phenomenon as "general mutagenesis" or "hypermutability".

Although the biological basis and significance of hypermutation is debated, the following features are not disputed. 1. Given the rate of adaptive mutation to $\mathrm{Lac}^{+}$, double mutants should be rare. Thus, cells with two mutations must have arisen from a hypermutating population.

1. Given the rate of adaptive mutation to $\mathrm{Lac}^{+}$, double mutants should be rare. Thus, cells with two mutations must have arisen from a hypermutating population.

2. The frequency of nonselected mutations among $\mathrm{Lac}^{+}$revertants increases linearly during five days incubation on lactose minimal medium. The simplest interpretation of this result is that the hypermutating cells are a constant proportion of the population and that they accumulate mutations at a steady rate thoughout the experiment. $(200,252)$.

3. In cells lacking Pol IV, the frequency of nonselected mutations among $\mathrm{Lac}^{+}$ revertants is significantly lower than in wild-type cells. Thus, Pol IV is required for the hypermutable state $(227,252)$.

4. Loss of MMR increases the frequency of nonselected mutations among $\mathrm{Lac}^{-}$cells 40-fold, but increases the frequency of nonselected mutations among $\mathrm{Lac}^{+}$cells less than 2-fold (200). Therefore, hypermutator cells must already be at least partially deficient in MMR.

5. In a MMR defective strain, the frequency of non-selected mutations is 10 -fold higher in double mutants ( $\mathrm{Lac}^{+}$revertants carrying a nonselected mutation) than in single mutants ( $\mathrm{Lac}^{+}$revertants) (200). Since all the double mutants must have experienced hypermutation, loss of MMR is not sufficient for hypermutation; thus, some other factor must be involved.

These observations led to the hypothesis that the hypermutation phenotype is due to both a decline of MMR and induction of Pol IV during lactose selection. These effects could be independent, or increased DNA polymerase errors due to Pol IV activity could saturate the cell's residual MMR capacity $(78,163,252)$. 
An alternative hypothesis is that hypermutation occurs in cells that have co-amplified the $\operatorname{din} B$ gene with the lac region (227). Such co-amplification is possible because of the proximity of $\operatorname{din} B$ and lac on the episome. However, placing the $\Phi$ (lacI33-lacZ) mutational target in its native location on the chromosome did not change the frequency of non-selected mutations among $\mathrm{Lac}^{+}$revertants (200). Because reversion to $\mathrm{Lac}^{+}$on the chromosome does not require RecA (84), and thus does not normally depend on amplification, it is unlikely that co-amplification of the $\operatorname{din} B$ gene with the lac allele explains the hypermutator phenotype.

Rosenberg and co-workers concluded that all $\mathrm{Lac}^{+}$revertants arise in the hypermutating population $(41,96,253)$. However, mathematical modeling indicated that hypermutators are about $0.1 \%$ of the $\mathrm{Lac}^{-}$population and account for only $10 \%$ of the single $\mathrm{Lac}^{+}$mutations (but nearly all of the double mutations) (200). These numbers are remarkably similar to those previously predicted by Ninio (176). A simpler way to think about the numbers is as follows. If all $\mathrm{Lac}^{+}$revertants occurred in hypermutator cells, then the frequency of additional mutations in single mutants $\left(\mathrm{Lac}^{+}\right.$revertants) and double mutants $\left(\mathrm{Lac}^{+}\right.$revertants with a second mutation) should be the same. But the former is only a tenth of the latter (200). Thus, most of the $\mathrm{Lac}^{+}$single mutants must have arisen in cells whose mutation rates was lower than that of the hypermutators (44).

There is also disagreement about the degree to which the mutation rate must be elevated in hypermutators to explain the frequency of $\mathrm{Lac}^{+}$mutations. In general, an estimated mutation rate about 200-fold higher than normal (in non-hypermutating cells) appears to fit the data $(41,200)$. A much lower estimate of 35 -fold was based on the mutagenic effect of SOS induction (209). The Roth group argues that if a small population of hypermutating cells gave rise to all the $\mathrm{Lac}^{+}$mutations, their mutation rate would have to be at least $10^{5}$-fold higher than normal; at that rate each $\mathrm{Lac}^{+}$mutant would carry an average of eight deleterious mutations, and thus could not be viable. However, this analysis does not take into account the fact that mutation rates on the episome are significantly higher than on the chromosome $(41,76,84,189,200)$. Thus, the likelihood that deleterious mutations accumulate on on the chromosome while $\mathrm{Lac}^{+}$reversion is occurring on the episome is orders of magnitude lower than estimated by Roth (209). In addition, if hypermutators account for only a minority of $\mathrm{Lac}^{+}$revertants, then the majority of cells are experiencing a much lower mutation rate (44).

Calculations of the size of the hypermutating population, as well as the contribution that hypermutator cells make to adaptive $\mathrm{Lac}^{+}$reversion are complex and rely on difficult measurements of the frequencies of single, double, and triple mutants. Thus, the role of hypermutation in adaptive mutation is not likely to be resolved to the satisfaction of all researchers in the field.

\section{Stress-Induced Mutation in Other Bacterial Systems}

Most of the results discussed in this module were obtained using laboratory strains of $E$. coli and Salmonella. While mechanisms of stress-induced mutation are best characterized in these domesticated organisms, other work has shown that the phenomenon is not restricted 
to E. coli and Salmonella, or to the laboratory, and that stress-induced mutation is likely to be a general phenomenon in microbes. For example, a phenomenon very similar to adaptive mutation in FC40 occurs in Pseudomonas putida (248). As in FC40, frameshift mutations increase during starvation conditions and are almost all due to the Pseudomonas homolog of Pol IV. However, these mutations are not recombination-dependent. In a separate study in $P$. putida, mutations creating an entirely new promoter sequence accumulated under selection (119). The mutations that arose included base substitutions, small deletions, and insertions of mobile genetic elements (217). When an auxotrophic strain of B. subtilis was plated on selective medium, prototrophic mutants appeared steadily over the course of nine days (240). Neither RecA nor the B. subtilis RpoS protein were required; however some of the mutations were due to YdjH, the Bacillus Pol IV homolog (241). Mirroring the hypermutating subpopulation in FC40 cells, MMR was deficient in some, but not all, of the B. subtilis cells, and about $1 \%$ of the prototrophic revertants carried nonselected mutations (181). Thus, hypermutating subpopulations may be a constant feature of stress-induced mutagenesis.

\section{Closing Remarks}

While the details of the various pathways vary, many mutagenic mechanisms appear to be stimulated by nutritional deprivation. The mechanisms by which mutation rates are increased during stress are often complex, energy consuming, and may have deleterious effects. Nevertheless, evolution has not selected against these pathways. But, it is not clear if the mutational state associated with a stress response was itself advantageous, or whether the mutational state is simply a necessary "evil" associated with survival functions. These are not necessarily exclusive hypotheses: the increased mutagenic potential associated with a trait originally selected for another purpose may nonetheless have significant evolutionary implications (78).

Stress-induced mutagenesis was initially thought to be a mechanism by which mutations could be "directed" to the specific loci that would alleviate selective pressures. Subsequent studies have revealed that this is not the case. However, this concept may need to be revisited in a more subtle form called "selective capture". Several hypotheses to explain directed mutation incorporated a "trial and error" mechanism $(25,45,232,233)$. The idea is that cells under selection are constantly experiencing potentially mutagenic DNA damage; if the damage does not result in an advantageous sequence change, it is repaired and the potential for mutation is lost. However, if a beneficial change occurs, the cell immediately begins to divide, and the beneficial change (as well as any other accompanying premutagenic lesions) is immortalized as a mutation. Data in support of this hypothesis were obtained by Bharatan and colleagues (21) by incubating lacI ${ }^{+}$lac $Z^{+}$E. coli on the noninducing lactose analog phenylgalactoside. The Lac constitutive mutants that arose early in the experiment carried recessive lacl $^{-}$mutations; however, after ten days of incubation all the mutants had dominant lac operator constitutive mutations. Bharatan and colleagues (21) proposed that the shift from recessive to dominant mutations reflected the need for "instantaneous gratification" in order to capture the sequence change. 
Many questions remain about the biological and evolutionary significance of stress-induced mutation, as well as about the underlying molecular mechanisms. Ongoing research is sure to provide more answers (and to generate more questions) as we move toward a more complete and universally accepted view of how microorganisms can adjust their mutation rates in response to exogenous or endogenous stress.

\section{Acknowledgments}

Work in the Foster laboratory is supported by USPHS NIH Grant GM065175 to P.L.F. We thank John Cairns for his continuing interest and collaboration.

\section{References}

1. Aertsen A, Michiels CW. Mrr instigates the SOS response after high pressure stress in Escherichia coli. Mol. Microbiol. 2005; 58:1381-91. [PubMed: 16313623]

2. Aertsen A, Tesfazgi Mebrhatu M, Michiels CW. Activation of the Salmonella typhimurium Mrr protein. Biochem. Biophys. Res. Commun. 2008; 367:435-9. [PubMed: 18178154]

3. Aertsen A, Van Houdt R, Vanoirbeek K, Michiels CW. An SOS response induced by high pressure in Escherichia coli. J. Bacteriol. 2004; 186:6133-41. [PubMed: 15342583]

4. Aguirre-Ramírez M, Ramírez-Santos J, Van Melderen L, Gómez-Eichelmann MC. Expression of the F plasmid $c c d$ toxin-antitoxin system in Escherichia coli cells under nutritional stress. Can. J. Microbiol. 2006; 52:24-30. [PubMed: 16541156]

5. Al Mamun AA, Marians KJ, Humayun MZ. DNA polymerase III from Escherichia coli cells expressing mutA mistranslator tRNA is error-prone. J. Biol. Chem. 2002; 277:46319-27. [PubMed: 12324458]

6. Al Mamun AA, Rahman MS, Humayun MZ. Escherichia coli cells bearing mutA, a mutant glyV tRNA gene, express a recA-dependent error-prone DNA replication activity. Mol. Microbiol. 1999; 33:732-40. [PubMed: 10447883]

7. Andersson DI, Slechta ES, Roth JR. Evidence that gene amplification underlies adaptive mutability of the bacterial lac operon. Science. 1998; 282:1133-1135. [PubMed: 9804552]

8. Autret S, Levine A, Vannier F, Fujita Y, Séror SJ. The replication checkpoint control in Bacillus subtilis: identification of a novel RTP-binding sequence essential for the replication fork arrest after induction of the stringent response. Mol. Microbiol. 1999; 31:1665-79. [PubMed: 10209741]

9. Bagdasarian M, Bailone A, Angulo JF, Scholz P, Bagdasarian M, Devoret R. PsiB, and anti-SOS protein, is transiently expressed by the $\mathrm{F}$ sex factor during its transmission to an Escherichia coli K-12 recipient. Mol. Microbiol. 1992; 6:885-893. [PubMed: 1318487]

10. Balashov S, Humayun MZ. Escherichia coli cells bearing a ribosomal ambiguity mutation in $r p s D$ have a mutator phenotype that correlates with increased mistranslation. J. Bacteriol. 2003; 185:5015-8. [PubMed: 12897024]

11. Balashov S, Humayun MZ. Mistranslation induced by streptomycin provokes a RecABC/ RuvABC-dependent mutator phenotype in Escherichia coli cells. J. Mol. Biol. 2002; 315:513-27. [PubMed: 11812126]

12. Barionovi D, Ghelardini P, Di Lallo G, Paolozzi L. Mutations arise independently of transcription in non-dividing bacteria. Mol. Genet. Genomics. 2003; 269:517-25. [PubMed: 12768413]

13. Battesti A, Majdalani N, Gottesman S. The RpoS-Mediated General Stress Response in Escherichia coli. Annu. Rev. Microbiol. 2011

14. Bearson SM, Benjamin WH Jr. Swords WE, Foster JW. Acid shock induction of RpoS is mediated by the mouse virulence gene mviA of Salmonella typhimurium. J. Bacteriol. 1996; 178:2572-9. [PubMed: 8626324]

15. Beletskii A, Bhagwat AS. Transcription-induced cytosine-to-thymine mutations are not dependent on sequence context of the target cytosine. J. Bacteriol. 2001; 183:6491-3. [PubMed: 11591695] 
16. Beletskii A, Bhagwat AS. Transcription-induced mutations: increases in $\mathrm{C}$ to $\mathrm{T}$ mutations in the nontranscribed strand during transcription in Escherichia coli. Proc. Natl. Acad. Sci. U.S.A. 1996; 93:13919-13924. [PubMed: 8943036]

17. Benov L, Fridovich I. The rate of adaptive mutagenesis in Escherichia coli is enhanced by oxygen (superoxide). Mutat. Res. 1996; 357:231-236. [PubMed: 8876699]

18. Bernard P, Couturier M. Cell killing by the F plasmid CcdB protein involves poisoning of DNAtopoisomerase II complexes. J. Mol. Biol. 1992; 226:735-45. [PubMed: 1324324]

19. Bernard P, Kézdy KE, Van Melderen L, Steyaert J, Wyns L, Pato ML, Higgins PN, Couturier M. The F plasmid CcdB protein induces efficient ATP-dependent DNA cleavage by gyrase. J. Mol. Biol. 1993; 234:534-41. [PubMed: 8254658]

20. Bhamre S, Gadea BB, Koyama CA, White SJ, Fowler RG. An aerobic recA-, umuC-dependent pathway of spontaneous base-pair substitution mutagenesis in Escherichia coli. Mutat. Res. 2001; 473:229-247. [PubMed: 11166040]

21. Bharatan SM, Reddy M, Gowrishankar J. Distinct signatures for mutator sensitivity of lacZ reversions and for the spectrum of lacI/lacO forward mutations on the chromosome of nondividing Escherichia coli. Genetics. 2004; 166:681-92. [PubMed: 15020459]

22. Biek DP, Cohen SN. Identification and characterization of recD, a gene affecting plasmid maintenance and recombination in Escherichia coli. J. Bacteriol. 1986; 167:594-603. [PubMed: 3015881]

23. Bjedov I, Dasgupta CN, Slade D, Le Blastier S, Selva M, Matic I. Involvement of Escherichia coli DNA polymerase IV in tolerance of cytotoxic alkylating DNA lesions in vivo. Genetics. 2007; 176:1431-40. [PubMed: 17483416]

24. Bjedov I, Tenaillon O, Gérard B, Souza V, Denamur E, Radman M, Taddei F, Matic I. Stressinduced mutagenesis in bacteria. Science. 2003; 300:1404-9. [PubMed: 12775833]

25. Boe L. Mechanism for induction of adaptive mutations in Escherichia coli. Mol. Microbiol. 1990; 4:597-601. [PubMed: 2191182]

26. Boshoff HI, Reed MB, Barry CE 3rd, Mizrahi V. DnaE2 polymerase contributes to in vivo survival and the emergence of drug resistance in Mycobacterium tuberculosis. Cell. 2003; 113:183-93. [PubMed: 12705867]

27. Bougdour A, Cunning C, Baptiste PJ, Elliott T, Gottesman S. Multiple pathways for regulation of sigmaS (RpoS) stability in Escherichia coli via the action of multiple anti-adaptors. Mol. Microbiol. 2008; 68:298-313. [PubMed: 18383615]

28. Bougdour A, Gottesman S. ppGpp regulation of RpoS degradation via anti-adaptor protein IraP. Proc. Natl. Acad. Sci. U.S.A. 2007; 104:12896-901. [PubMed: 17640895]

29. Brake AJ, Fowler AV, Zabin I, Kania J, Müller-Hill B. $\beta$-galactosidase chimeras: primary structure of a lac repressor-b-galactosidase protein. Proc. Natl. Acad. Sci. U.S.A. 1978; 75:4824-4827. [PubMed: 105358]

30. Bridges BA. DNA turnover and mutation in resting cells. Bioessays. 1997; 19:347-52. [PubMed: 9136632]

31. Bridges BA. mutY 'directs' mutation? Nature (London). 1995; 375:741. [PubMed: 7596405]

32. Bridges BA. The role of DNA damage in stationary phase ('adaptive') mutation. Mutat. Res. 1998; 408:1-9. [PubMed: 9678058]

33. Bridges BA. Starvation-associated mutation in Escherichia coli strains defective in transcription repair coupling factor. Mutat. Res. 1995; 329:49-56. [PubMed: 7770075]

34. Bridges BA, Foster PL, Timms AR. Effect of endogenous carotenoids on "adaptive" mutation in Escherichia coli FC40. Mutat. Res. 2001; 473:109-119. [PubMed: 11166030]

35. Bridges BA, Sekiguchi M, Tajiri T. Effect of mut $Y$ and mutM/fpg- 1 mutations on starvationassociated mutation in Escherichia coli: implications for the role of 7,8-dihydro-8-oxoguanine. Mol. Gen. Genet. 1996; 251:352-357. [PubMed: 8676878]

36. Bridges BA, Timms A. Effect of endogenous carotenoids and defective RpoS sigma factor on spontaneous mutation under starvation conditions in Escherichia coli: evidence for the possible involvement of singlet oxygen. Mutat. Res. 1998; 403:21-8. [PubMed: 9726002] 
37. Brotcorne-Lannoye A, Maenhaut-Michel G. Role of RecA protein in untargeted UV mutagenesis of bacteriophage lambda: evidence for the requirement for the dinB gene. Proc. Natl. Acad. Sci. U.S.A. 1986; 83:3904-8. [PubMed: 2940594]

38. Brown L, Gentry D, Elliott T, Cashel M. DksA affects ppGpp induction of RpoS at a translational level. J. Bacteriol. 2002; 184:4455-65. [PubMed: 12142416]

39. Brown MR, Kornberg A. Inorganic polyphosphate in the origin and survival of species. Proc. Natl. Acad. Sci. U.S.A. 2004; 101:16085-7. [PubMed: 15520374]

40. Buettner MJ, Spitz E, Rickenberg HV. Cyclic adenosine 3',5'-monophosphate in Escherichia coli. J. Bacteriol. 1973; 114:1068-73. [PubMed: 4351386]

41. Bull HJ, McKenzie GJ, Hastings PJ, Rosenberg SM. Evidence that stationary-phase hypermutation in the Escherichia coli chromosome is promoted by recombination. Genetics. 2000; 154:14271437. [PubMed: 10747042]

42. Cairns J. Mutation and cancer: The antecedents to our studies of adaptive mutation. Genetics. 1998; 148:1433-1440. [PubMed: 9560363]

43. Cairns J, Foster PL. Adaptive reversion of a frameshift mutation in Escherichia coli. Genetics. 1991; 128:695-701. [PubMed: 1916241]

44. Cairns J, Foster PL. The risk of lethals for hypermutating bacteria in stationary phase. Genetics. 2003; 165:2317-2318. [PubMed: 14738105]

45. Cairns J, Overbaugh J, Miller S. The origin of mutants. Nature (London). 1988; 335:142-145. [PubMed: 3045565]

46. Calos MP, Miller JH. Genetic and sequence analysis of frameshift mutations induced by ICR-191. J. Mol. Biol. 1981; 153:39-66. [PubMed: 7040679]

47. Charette MF, Henderson GW, Doane LL, Markovitz A. DNA-stimulated ATPase activity on the Lon (CapR) protein. J. Bacteriol. 1984; 158:195-201. [PubMed: 6325386]

48. Cirz RT, Chin JK, Andes DR, de Crecy-Lagard V, Craig WA, Romesberg FE. Inhibition of mutation and combating the evolution of antibiotic resistance. PLoS Biol. 2005; 3:e176. [PubMed: 15869329]

49. Cirz RT, Romesberg FE. Controlling mutation: intervening in evolution as a therapeutic strategy. Crit. Rev. Biochem. Mol. Biol. 2007; 42:341-54. [PubMed: 17917871]

50. Claret L, Rouvière-Yaniv J. Variation in HU composition during growth of Escherichia coli: the heterodimer is required for long term survival. J. Mol. Biol. 1997; 273:93-104. [PubMed: 9367749]

51. Cohen SE, Godoy VG, Walker GC. Transcriptional modulator NusA interacts with translesion DNA polymerases in Escherichia coli. J. Bacteriol. 2009; 191:665-72. [PubMed: 18996995]

52. Cohen SE, Walker GC. The transcription elongation factor NusA is required for stress-induced mutagenesis in Escherichia coli. Curr. Biol. 2010; 20:80-5. [PubMed: 20036541]

53. Couch J, Hanawalt PC. DNA repair replication in temperature-sensitive DNA synthesis deficient bacteria. Biochem. Biophys. Res. Commun. 1967; 29:779-84. [PubMed: 4865116]

54. Courcelle J, Khodursky A, Peter B, Brown PO, Hanawalt PC. Comparative gene expression profiles following UV exposure in wild-type and SOS-deficient Escherichia coli. Genetics. 2001; 158:41-64. [PubMed: 11333217]

55. Couturier M, el-M B, Van Melderen L. Bacterial death by DNA gyrase poisoning. Trends Microbiol. 1998; 6:269-75. [PubMed: 9717215]

56. Curti E, McDonald JP, Mead S, Woodgate R. DNA polymerase switching: effects on spontaneous mutagenesis in Escherichia coli. Mol. Microbiol. 2008; 71:315-31. [PubMed: 19019142]

57. Datta A, Jinks-Robertson S. Association of increased spontaneous mutation rates with high levels of transcription in yeast. Science. 1995; 268:1616-1619. [PubMed: 7777859]

58. Davis BD. Transcriptional bias: A non-Lamarckian mechanism for substrate-induced mutations. Proc. Natl. Acad. Sci. U.S.A. 1989; 86:5005-5009. [PubMed: 2740338]

59. Dong T, Kirchhof MG, Schellhorn HE. RpoS regulation of gene expression during exponential growth of Escherichia coli K-12. Mol. Genet. Genomics. 2008; 279:267-77. [PubMed: 18158608]

60. Donnelly CE, Walker GC. Coexpression of UmuD' with UmuC suppresses the UV mutagenesis deficiency of groE mutants. J. Bacteriol. 1992; 174:3133-3139. [PubMed: 1349601] 
61. Donnelly CE, Walker GC. groE mutants of Escherichia coli are defective in umuDC-dependent UV mutagenesis. J. Bacteriol. 1989; 171:6117-6125. [PubMed: 2572581]

62. Drake JW. A constant rate of spontaneous mutation in DNA-based microbes. Proc. Natl. Acad. Sci. U.S.A. 1991; 88:7160-7164. [PubMed: 1831267]

63. Dri AM, Moreau PL. Control of the LexA regulon by $\mathrm{pH}$ : evidence for a reversible inactivation of the LexA repressor during the growth cycle of Escherichia coli. Mol. Microbiol. 1994; 12:621629. [PubMed: 7934886]

64. Drlica K, Zhao X. DNA gyrase, topoisomerase IV, and the 4-quinolones. Microbiol. Mol. Biol. Rev. 1997; 61:377-92. [PubMed: 9293187]

65. Durfee T, Hansen AM, Zhi H, Blattner FR, Jin DJ. Transcription profiling of the stringent response in Escherichia coli. J. Bacteriol. 2008; 190:1084-96. [PubMed: 18039766]

66. Eisenstark A, Miller C, Jones J, Levén S. Escherichia coli genes involved in cell survival during dormancy: role of oxidative stress. Biochem. Biophys. Res. Commun. 1992; 188:1054-9. [PubMed: 1445342]

67. Erill I, Campoy S, Barbe J. Aeons of distress: an evolutionary perspective on the bacterial SOS response. FEMS Microbiol. Rev. 2007; 31:637-56. [PubMed: 17883408]

68. Escarceller M, Hicks J, Gudmundsson G, Trump G, Touati D, Lovett S, Foster PL, McEntee K, Goodman MF. Involvement of Escherichia coli DNA polymerase II in response to oxidative damage and adaptive mutation. J. Bacteriol. 1994; 176:6221-8. [PubMed: 7928992]

69. Feng G, Tsui HC, Winkler ME. Depletion of the cellular amounts of the MutS and MutH methyldirected mismatch repair proteins in stationary-phase Escherichia coli K-12 cells. J. Bacteriol. 1996; 178:2388-96. [PubMed: 8636043]

70. Fernández De Henestrosa AR, Ogi T, Aoyagi S, Chafin D, Hayes JJ, Ohmori H, Woodgate R. Identification of additional genes belonging to the LexA regulon in Escherichia coli. Mol. Microbiol. 2000; 35:1560-72. [PubMed: 10760155]

71. Fitch WM. The challenges to Darwinism since the last centennial and the impact of molecular studies. Evolution. 1982; 36(6):1133-1143.

72. Foster PL. Adaptive mutation in Escherichia coli. Cold Spring Harb. Symp. Quant. Biol. 2000; 65:21-29. [PubMed: 12760017]

73. Foster PL. Adaptive Mutation in Escherichia coli. J. Bacteriol. 2004; 186:4846-4852. [PubMed: 15262917]

74. Foster PL. Adaptive mutation: The uses of adversity. Annu. Rev. Microbiol. 1993; 47:467-504. [PubMed: 8257106]

75. Foster PL. Are adaptive mutations due to a decline in mismatch repair? The evidence is lacking. Mutat. Res. 1999; 436:179-184. [PubMed: 10095139]

76. Foster PL. Nonadaptive mutations occur on the $\mathrm{F}^{\prime}$ episome during adaptive mutation conditions in Escherichia coli. J. Bacteriol. 1997; 179:1550-1554. [PubMed: 9045812]

77. Foster PL. Population dynamics of a Lac- strain of Escherichia coli during selection for lactose utilization. Genetics. 1994; 138:253-261. [PubMed: 7828809]

78. Foster PL. Stress-induced mutagenesis in bacteria. Crit. Rev. Biochem. Mol. Biol. 2007; 42:37397. [PubMed: 17917873]

79. Foster, PL. unpublished

80. Foster PL, Cairns J. Mechanisms of directed mutation. Genetics. 1992; 131:783-789. [PubMed: 1516815]

81. Foster PL, Gudmundsson G, Trimarchi JM, Cai H, Goodman MF. Proofreading-defective DNA polymerase II increases adaptive mutation in Escherichia coli. Proc. Natl. Acad. Sci. U.S.A. 1995; 92:7951-7955. [PubMed: 7644519]

82. Foster PL, Rosche WA. Increased episomal replication accounts for the high rate of adaptive mutation in recD mutants of Escherichia coli. Genetics. 1999; 152:15-30. [PubMed: 10224241]

83. Foster PL, Trimarchi JM. Adaptive reversion of a frameshift mutation in Escherichia coli by simple base deletions in homopolymeric runs. Science. 1994; 265:407-409. [PubMed: 8023164] 
84. Foster PL, Trimarchi JM. Adaptive reversion of an episomal frameshift mutation in Escherichia coli requires conjugal functions but not actual conjugation. Proc. Natl. Acad. Sci. U.S.A. 1995; 92:5487-5490. [PubMed: 7777535]

85. Foster PL, Trimarchi JM. Conjugation is not required for adaptive reversion of an episomal frameshift mutation in Escherichia coli. J. Bacteriol. 1995; 177:6670-6671. [PubMed: 7592449]

86. Foster PL, Trimarchi JM, Maurer RA. Two enzymes, both of which process recombination intermediates, have opposite effects on adaptive mutation in Escherichia coli. Genetics. 1996; 142:25-37. [PubMed: 8770582]

87. Frost LS, Manchak J. F- phenocopies: characterization of expression of the F transfer region in stationary phase. Microbiology. 1998; 144:2579-2587. [PubMed: 9782507]

88. Galan JC, Turrientes MC, Baquero MR, Rodriguez-Alcayna M, Martinez-Amado J, Martinez JL, Baquero F. Mutation rate is reduced by increased dosage of mutL gene in Escherichia coli K-12. FEMS Microbiol. Lett. 2007; 275:263-9. [PubMed: 17825069]

89. Galhardo RS, Do R, Yamada M, Friedberg EC, Hastings PJ, Nohmi T, Rosenberg SM. DinB upregulation is the sole role of the SOS response in stress-induced mutagenesis in Escherichia coli. Genetics. 2009; 182:55-68. [PubMed: 19270270]

90. Galitski T, Roth JR. Evidence that F plasmid transfer replication underlies apparent adaptive mutation. Science. 1995; 268:421-423. [PubMed: 7716546]

91. Gentry DR, Hernandez VJ, Nguyen LH, Jensen DB, Cashel M. Synthesis of the stationary-phase sigma factor sigma $\mathrm{s}$ is positively regulated by ppGpp. J. Bacteriol. 1993; 175:7982-7989. [PubMed: 8253685]

92. Giangrossi M, Giuliodori AM, Gualerzi CO, Pon CL. Selective expression of the beta-subunit of nucleoid-associated protein HU during cold shock in Escherichia coli. Mol. Microbiol. 2002; 44:205-16. [PubMed: 11967080]

93. Gibson JL, Lombardo MJ, Thornton PC, Hu KH, Galhardo RS, Beadle B, Habib A, Magner DB, Frost LS, Herman C, Hastings PJ, Rosenberg SM. The sigma(E) stress response is required for stress-induced mutation and amplification in Escherichia coli. Mol. Microbiol. 2010; 77:415-30. [PubMed: 20497332]

94. Godoy VG, Jarosz DF, Simon SM, Abyzov A, Ilyin V, Walker GC. UmuD and RecA directly modulate the mutagenic potential of the Y family DNA polymerase DinB. Mol. Cell. 2007; 28:1058-70. [PubMed: 18158902]

95. Gómez-Gómez JM, Blázquez J, Baquero F, Martínez JL. H-NS and RpoS regulate emergence of $\mathrm{Lac} \mathrm{Ara}^{+}$mutants of Escherichia coli MCS2. J. Bacteriol. 1997; 179:4620-2. [PubMed: 9226274]

96. Gonzalez C, Hadany L, Ponder RG, Price M, Hastings PJ, Rosenberg SM. Mutability and importance of a hypermutable cell subpopulation that produces stress-induced mutants in Escherichia coli. PLoS Genet. 2008; 4:e1000208. [PubMed: 18833303]

97. Gourse RL, Keck JL. Magic spots cast a spell on DNA primase. Cell. 2007; 128:823-4. [PubMed: 17350566]

98. Grigg GW, Stuckey J. The reversible suppression of stationary phase mutation in Escherichia coli by caffeine. Genetics. 1966; 53:823-834. [PubMed: 5333373]

99. Grivell AR, Grivell MB, Hanawalt PC. Turnover in bacterial DNA containing thymine or 5bromouracil. J. Mol. Biol. 1975; 98:219-33. [PubMed: 1104866]

100. Gruber TM, Gross CA. Multiple sigma subunits and the partitioning of bacterial transcription space. Annu. Rev. Microbiol. 2003; 57:441-66. [PubMed: 14527287]

101. Hall BG. Selection-induced mutations occur in yeast. Proc. Natl. Acad. Sci. U.S.A. 1992; 89:4300-4303. [PubMed: 1584764]

102. Hall BG. Spontaneous point mutations that occur more often when they are advantageous than when they are neutral. Genetics. 1990; 126:5-16. [PubMed: 2227388]

103. Hanawalt PC, Pettijohn DE, Pauling EC, Brunk CF, Smith DW, Kanner LC, Couch JL. Repair replication of DNA in vivo. Cold Spring Harb. Symp. Quant. Biol. 1968; 33:187-94. [PubMed: 4891962]

104. Harris RS, Feng G, Ross KJ, Sidhu R, Thulin C, Longerich S, Szigety SK, Hastings PJ, Winkler ME, Rosenberg SM. Mismatch repair is diminished during stationary-phase mutation. Mutat. Res. 1999; 437:51-60. [PubMed: 10425389] 
105. Harris RS, Feng G, Ross KJ, Sidhu R, Thulin C, Longerich S, Szigety SK, Winkler ME, Rosenberg SM. Mismatch repair protein MutL becomes limiting during stationary-phase mutation. Genes Dev. 1997; 11:2426-2437. [PubMed: 9308969]

106. Harris RS, Longerich S, Rosenberg SM. Recombination in adaptive mutation. Science. 1994; 264:258-260. [PubMed: 8146657]

107. Harris RS, Ross KJ, Rosenberg SM. Opposing roles of the Holliday junction processing systems of Escherichia coli in recombination-dependent adaptive mutation. Genetics. 1996; 142:681-691. [PubMed: 8849879]

108. Hastings PJ, Bull HJ, Klump JR, Rosenberg SM. Adaptive amplification: an inducible chromosomal instability mechanism. Cell. 2000; 103:723-31. [PubMed: 11114329]

109. Hastings PJ, Hersh MN, Thornton PC, Fonville NC, Slack A, Frisch RL, Ray MP, Harris RS, Leal SM, Rosenberg SM. Competition of Escherichia coli DNA polymerases I, II and III with DNA Pol IV in stressed cells. PLoS ONE. 2010; 5:e10862. [PubMed: 20523737]

110. He AS, Rohatgi PR, Hersh MN, Rosenberg SM. Roles of E. coli double-strand-break-repair proteins in stress-induced mutation. DNA Repair (Amst). 2006; 5:258-73. [PubMed: 16310415]

111. Hendriks G, Calleja F, Vrieling H, Mullenders LH, Jansen JG, de Wind N. Gene transcription increases DNA damage-induced mutagenesis in mammalian stem cells. DNA Repair (Amst). 2008; 7:1330-9. [PubMed: 18539547]

112. Hiraga S, Jaffé A, Ogura T, Mori H, Takahashi H. F plasmid $c c d$ mechanism in Escherichia coli. J. Bacteriol. 1986; 166:100-4. [PubMed: 3007430]

113. Ilves H, Hõrak R, Kivisaar M. Involvement of sigma(S) in starvation-induced transposition of Pseudomonas putida transposon Tn4652. J. Bacteriol. 2001; 183:5445-8. [PubMed: 11514532]

114. Indiani C, Langston LD, Yurieva O, Goodman MF, O'Donnell M. Translesion DNA polymerases remodel the replisome and alter the speed of the replicative helicase. Proc. Natl. Acad. Sci. U.S.A. 2009; 106:6031-8. [PubMed: 19279203]

115. Iwasaki H, Nakata A, Walker GC, Shinagawa H. The Escherichia coli polB gene, which encodes DNA Polymerase II, is regulated by the SOS system. J. Bacteriol. 1990; 172:6268-6273. [PubMed: 2228959]

116. Janion C. A new look at adaptive mutations in bacteria. Acta Biochim. Pol. 2000; 47:451-7. [PubMed: 11051210]

117. Janion C, Sikora A, Nowosielska A, Grzesiuk E. Induction of the SOS response in starved Escherichia coli. Environ. Mol. Mutagen. 2002; 40:129-33. [PubMed: 12203406]

118. Jarosz DF, Godoy VG, Delaney JC, Essigmann JM, Walker GC. A single amino acid governs enhanced activity of DinB DNA polymerases on damaged templates. Nature. 2006; 439:225-8. [PubMed: 16407906]

119. Kasak L, Hõrak R, Kivisaar M. Promoter-creating mutations in Pseudomonas putida: a model system for the study of mutation in starving bacteria. Proc. Natl. Acad. Sci. U.S.A. 1997; 94:3134-9. [PubMed: 9096358]

120. Kelley WL. Lex marks the spot: the virulent side of SOS and a closer look at the LexA regulon. Mol. Microbiol. 2006; 62:1228-38. [PubMed: 17042786]

121. Kenyon CJ, Brent R, Ptashne M, Walker GC. Regulation of damage-inducible genes in Escherichia coli. J. Mol. Biol. 1982; 160:445-457. [PubMed: 6818350]

122. Khodursky AB, Cozzarelli NR. The mechanism of inhibition of topoisomerase IV by quinolone antibacterials. J. Biol. Chem. 1998; 273:27668-77. [PubMed: 9765303]

123. Kim SR, Maenhaut-Michel G, Yamada M, Yamamoto Y, Matsui K, Sofuni T, Nohmi T, Ohmori H. Multiple pathways for SOS-induced mutagenesis in Escherichia coli: an overexpression of $\operatorname{din} B / \operatorname{din} P$ results in strongly enhancing mutagenesis in the absence of any exogenous treatment to damage DNA. Proc. Natl. Acad. Sci. U.S.A. 1997; 94:13792-13797. [PubMed: 9391106]

124. Kim SR, Matsui K, Yamada M, Gruz P, Nohmi T. Roles of chromosomal and episomal dinB genes encoding DNA pol IV in targeted and untargeted mutagenesis in Escherichia coli. Mol. Genet. Genomics. 2001; 266:207-15. [PubMed: 11683261]

125. Klapacz J, Bhagwat AS. Transcription promotes guanine to thymine mutations in the nontranscribed strand of an Escherichia coli gene. DNA Repair (Amst). 2005; 4:806-13. [PubMed: 15961353] 
126. Klapacz J, Bhagwat AS. Transcription-dependent increase in multiple classes of base substitution mutations in Escherichia coli. J. Bacteriol. 2002; 184:6866-72. [PubMed: 12446637]

127. Kobayashi S, Valentine MR, Pham P, O'Donnell M, Goodman MF. Fidelity of Escherichia coli DNA polymerase IV. Preferential generation of small deletion mutations by dNTP-stabilized misalignment. J. Biol. Chem. 2002; 277:34198-34207. [PubMed: 12097328]

128. Koch WH, Fernández De Henestrosa AR, Woodgate R. Identification of mucAB-like homologs on two IncT plasmids, R394 and Rts-1. Mutat. Res. 2000; 457:1-13. [PubMed: 11106794]

129. Kofoid E, Bergthorsson U, Slechta ES, Roth JR. Formation of an F' Plasmid by Recombination between Imperfectly Repeated Chromosomal rep Sequences: a Closer Look at an Old Friend (F'128 pro lac). J. Bacteriol. 2003; 185:660-663. [PubMed: 12511513]

130. Koorits L, Tegova R, Tark M, Tarassova K, Tover A, Kivisaar M. Study of involvement of ImuB and DnaE2 in stationary-phase mutagenesis in Pseudomonas putida. DNA Repair (Amst). 2007; 6:863-8. [PubMed: 17331811]

131. Kornberg A, Rao NN, Ault-Riché D. Inorganic polyphosphate: a molecule of many functions. Annu. Rev. Biochem. 1999; 68:89-125. [PubMed: 10872445]

132. Kuban W, Banach-Orlowska M, Schaaper RM, Jonczyk P, Fijalkowska IJ. Role of DNA polymerase IV in Escherichia coli SOS mutator activity. J. Bacteriol. 2006; 188:7977-80. [PubMed: 16980447]

133. Kuban W, Jonczyk P, Gawel D, Malanowska K, Schaaper RM, Fijalkowska IJ. Role of Escherichia coli DNA polymerase IV in in vivo replication fidelity. J. Bacteriol. 2004; 186:48024807. [PubMed: 15231812]

134. Kulaev IS, Vagabov VM. Polyphosphate metabolism in micro-organisms. Adv. Microb. Physiol. 1983; 24:83-171. [PubMed: 6320606]

135. Kumble KD, Kornberg A. Inorganic polyphosphate in mammalian cells and tissues. J. Biol. Chem. 1995; 270:5818-22. [PubMed: 7890711]

136. Kunkel TA, Erie DA. DNA mismatch repair. Annu. Rev. Biochem. 2005; 74:681-710. [PubMed: 15952900]

137. Kuroda A. A polyphosphate-lon protease complex in the adaptation of Escherichia coli to amino acid starvation. Biosci. Biotechnol. Biochem. 2006; 70:325-31. [PubMed: 16495646]

138. Kuroda A, Murphy H, Cashel M, Kornberg A. Guanosine tetra- and pentaphosphate promote accumulation of inorganic polyphosphate in Escherichia coli. J. Biol. Chem. 1997; 272:21240-3. [PubMed: 9261133]

139. Kusano S, Ishihama A. Functional interaction of Escherichia coli RNA polymerase with inorganic polyphosphate. Genes Cells. 1997; 2:433-41. [PubMed: 9366549]

140. Kuzminov A. Collapse and repair of replication forks in Escherichia coli. Mol. Microbiol. 1995; 16:373-384. [PubMed: 7565099]

141. Kvint K, Farewell A, Nyström T. RpoS-dependent promoters require guanosine tetraphosphate for induction even in the presence of high levels of sigma(s). J. Biol. Chem. 2000; 275:14795-8. [PubMed: 10747855]

142. Lacour S, Landini P. SigmaS-dependent gene expression at the onset of stationary phase in Escherichia coli: function of sigmaS-dependent genes and identification of their promoter sequences. J. Bacteriol. 2004; 186:7186-95. [PubMed: 15489429]

143. Lange R, Fischer D, Hengge-Aronis R. Identification of transcriptional start sites and the role of ppGpp in the expression of rpoS, the structural gene for the sigma S subunit of RNA polymerase in Escherichia coli. J. Bacteriol. 1995; 177:4676-80. [PubMed: 7642494]

144. Lawley TD, Klimke WA, Gubbins MJ, Frost LS. F factor conjugation is a true type IV secretion system. FEMS Microbiol. Lett. 2003; 224:1-15. [PubMed: 12855161]

145. Layton JC, Foster PL. Error-prone DNA polymerase IV is controlled by the stress-response sigma factor, RpoS, in Escherichia coli. Mol. Microbiol. 2003; 50:549-561. [PubMed: 14617178]

146. Layton JC, Foster PL. Error-prone DNA polymerase IV is regulated by the heat shock chaperone GroE in Escherichia coli. J. Bacteriol. 2005; 187:449-57. [PubMed: 15629916]

147. Lederberg J, Lederberg E. Replica plating and indirect selection of bacterial mutants. J. Bacteriol. 1952; 63:399-406. [PubMed: 14927572] 
148. Lenne-Samuel N, Janel-Bintz R, Kolbanovskiy A, Geacintov NE, Fuchs RP. The processing of a Benzo(a)pyrene adduct into a frameshift or a base substitution mutation requires a different set of genes in Escherichia coli. Mol. Microbiol. 2000; 38:299-307. [PubMed: 11069656]

149. Lindahl T. Instability and decay of the primary structure of DNA. Nature (London). 1993; 362:709-715. [PubMed: 8469282]

150. Little JW. Mechanism of specific LexA cleavage: autodigestion and the role of RecA coprotease. Biochimie. 1991; 73:411-421. [PubMed: 1911941]

151. Liu SK, Tessman I. groE genes affect SOS repair in Escherichia coli. J. Bacteriol. 1990; 172:6135-6138. [PubMed: 2211529]

152. Lloyd RG, Buckman C. Genetic analysis of the recG locus of Escherichia coli $\mathrm{K}-12$ and of its role in recombination and DNA repair. J. Bacteriol. 1991; 173:1004-11. [PubMed: 1846849]

153. Lombardo MJ, Aponyi I, Rosenberg SM. General stress response regulator RpoS in adaptive mutation and amplification in Escherichia coli. Genetics. 2004; 166:669-680. [PubMed: 15020458]

154. Longerich S, Galloway AM, Harris RS, Wong C, Rosenberg SM. Adaptive mutation sequences reproduced by mismatch repair deficiency. Proc. Natl. Acad. Sci. U.S.A. 1995; 92:12017-20. [PubMed: 8618835]

155. Lovett ST, Luisi-DeLuca C, Kolodner RD. The genetic dependence of recombination in recD mutants of Escherichia coli. Genetics. 1988; 120:37-45. [PubMed: 3065139]

156. Luria SE, Delbruck M. Mutations of bacteria from virus sensitivity to virus resistance. Genetics. 1943; 28:491-511. [PubMed: 17247100]

157. Macheboeuf P, Contreras-Martel C, Job V, Dideberg O, Dessen A. Penicillin binding proteins: key players in bacterial cell cycle and drug resistance processes. FEMS Microbiol. Rev. 2006; 30:673-91. [PubMed: 16911039]

158. Mackay WJ, Han S, Samson LD. DNA alkylation repair limits spontaneous base substitution mutations in Escherichia coli. J. Bacteriol. 1994; 176:3224-3230. [PubMed: 8195077]

159. Mamber SW, Kolek B, Brookshire KW, Bonner DP, Fung-Tomc J. Activity of quinolones in the Ames Salmonella TA102 mutagenicity test and other bacterial genotoxicity assays. Antimicrob. Agents Chemother. 1993; 37:213-7. [PubMed: 8452351]

160. McCool JD, Long E, Petrosino JF, Sandler HA, Rosenberg SM, Sandler SJ. Measurement of SOS expression in individual Escherichia coli K-12 cells using fluorescence microscopy. Mol. Microbiol. 2004; 53:1343-57. [PubMed: 15387814]

161. McGlynn P, Lloyd RG. Recombinational repair and restart of damaged replication forks. Nat. Rev. Mol. Cell. Biol. 2002; 3:859-70. [PubMed: 12415303]

162. McKenzie GJ, Harris RS, Lee PL, Rosenberg SM. The SOS response regulates adaptive mutation. Proc. Natl. Acad. Sci. U.S.A. 2000; 97:6646-6651. [PubMed: 10829077]

163. McKenzie GJ, Lee PL, Lombardo MJ, Hastings PJ, Rosenberg SM. SOS Mutator DNA polymerase IV functions in adaptive mutation and not adaptive amplification. Mol. Cell. 2001; 7:571-579. [PubMed: 11463382]

164. Mead S, Vaisman A, Valjavec-Gratian M, Karata K, Vandewiele D, Woodgate R. Characterization of polVR391: a Y-family polymerase encoded by rumA'B from the IncJ conjugative transposon, R391. Mol. Microbiol. 2007; 63:797-810. [PubMed: 17302804]

165. Mellon I. Transcription-coupled repair: a complex affair. Mutat. Res. 2005; 577:155-61. [PubMed: 15913669]

166. Michaels ML, Miller JH. The GO system protects organisms from the mutagenic effect of the spontaneous lesion 8-hydroxyguanine (7,8-dihydro-8-oxoguanine). J. Bacteriol. 1992; 174:63216325. [PubMed: 1328155]

167. Miller C, Thomsen LE, Gaggero C, Mosseri R, Ingmer H, Cohen SN. SOS response induction by beta-lactams and bacterial defense against antibiotic lethality. Science. 2004; 305:1629-31. [PubMed: 15308764]

168. Miller, JH. A short course in bacterial genetics: a laboratory manual and handbook for Escherichia coli and related bacteria. Cold Spring Harbor Laboratory Press; Cold Spring Harbor: 1992. 
169. Miller JH. Spontaneous mutators in bacteria: insights into pathways of mutagenesis and repair. Annu. Rev. Microbiol. 1996; 50:625-643. [PubMed: 8905093]

170. Miyachi S. Inorganic polyphosphate in spinach leaves. J. Biochem. 1961; 50:367-71. [PubMed: 14474776]

171. Muffler A, Fischer D, Altuvia S, Storz G, Hengge-Aronis R. The response regulator RssB controls stability of the sigma(S) subunit of RNA polymerase in Escherichia coli. EMBO J. 1996; 15:1333-9. [PubMed: 8635466]

172. Muller HJ. The Relation of Recombination to Mutational Advance. Mutat. Res. 1964; 106:2-9. [PubMed: 14195748]

173. Müller-Hill B, Kania J. Lac repressor can be fused to b-galactosidase. Nature (London). 1974; 249:561-562. [PubMed: 4599764]

174. Nakada D, Ryan FJ. Replication of deoxyribonucleic acid in non-dividing bacteria. Nature (London). 1961; 189:398-399. [PubMed: 13727575]

175. Napolitano R, Janel-Bintz R, Wagner J, Fuchs RPP. All three SOS-inducible DNA polymerases (Pol II, Pol IV and Pol V) are involved in induced mutagenesis. EMBO J. 2000; 19:6259-6265. [PubMed: 11080171]

176. Ninio J. Transient mutators: A semiquantitative analysis of the influence of translation and transcription errors on mutation rates. Genetics. 1991; 129:957-962. [PubMed: 1752431]

177. Nomura K, Kato J, Takiguchi N, Ohtake H, Kuroda A. Effects of inorganic polyphosphate on the proteolytic and DNA-binding activities of Lon in Escherichia coli. J. Biol. Chem. 2004; 279:34406-10. [PubMed: 15187082]

178. O'Reilly EK, Kreuzer KN. Isolation of SOS constitutive mutants of Escherichia coli. J. Bacteriol. 2004; 186:7149-60. [PubMed: 15489426]

179. Patel M, Jiang Q, Woodgate R, Cox MM, Goodman MF. A new model for SOS-induced mutagenesis: how RecA protein activates DNA polymerase V. Crit. Rev. Biochem. Mol. Biol. 2010; 45:171-84. [PubMed: 20441441]

180. Patten CL, Kirchhof MG, Schertzberg MR, Morton RA, Schellhorn HE. Microarray analysis of RpoS-mediated gene expression in Escherichia coli K-12. Mol. Genet. Genomics. 2004; 272:580-91. [PubMed: 15558318]

181. Pedraza-Reyes M, Yasbin RE. Contribution of the mismatch DNA repair system to the generation of stationary-phase-induced mutants of Bacillus subtilis. J. Bacteriol. 2004; 186:6485-91. [PubMed: 15375129]

182. Pérez-Capilla T, Baquero MR, Gómez-Gómez JM, Ionel A, Martín S, Blázquez J. SOSindependent induction of $\operatorname{din} B$ transcription by beta-lactam-mediated inhibition of cell wall synthesis in Escherichia coli. J .Bacteriol. 2005; 187:1515-8. [PubMed: 15687217]

183. Petrosino JF, Galhardo RS, Morales LD, Rosenberg SM. Stress-induced beta-lactam antibiotic resistance mutation and sequences of stationary-phase mutations in the Escherichia coli chromosome. J. Bacteriol. 2009; 191:5881-9. [PubMed: 19648247]

184. Pinson V, Takahashi M, Rouviere-Yaniv J. Differential binding of the Escherichia coli HU, homodimeric forms and heterodimeric form to linear, gapped and cruciform DNA. J. Mol. Biol. 1999; 287:485-97. [PubMed: 10092454]

185. Ponder RG, Fonville NC, Rosenberg SM. A switch from high-fidelity to error-prone DNA double-strand break repair underlies stress-induced mutation. Mol. Cell. 2005; 19:791-804. [PubMed: 16168374]

186. Powell SC, Wartell RM. Different characteristics distinguish early versus late arising adaptive mutations in Escherichia coli FC40. Mutat. Res. 2001; 473:219-228. [PubMed: 11166039]

187. Pratt LA, Silhavy TJ. The response regulator SprE controls the stability of RpoS. Proc. Natl. Acad. Sci. U.S.A. 1996; 93:2488-92. [PubMed: 8637901]

188. Quillardet P, Rouffaud MA, Bouige P. DNA array analysis of gene expression in response to UV irradiation in Escherichia coli. Res. Microbiol. 2003; 154:559-72. [PubMed: 14527657]

189. Radicella JP, Park PU, Fox MS. Adaptive mutation in Escherichia coli: A role for conjugation. Science. 1995; 268:418-420. [PubMed: 7716545]

190. Rahman M, Hasan MR, Oba T, Shimizu K. Effect of rpoS gene knockout on the metabolism of Escherichia coli during exponential growth phase and early stationary phase based on gene 
expressions, enzyme activities and intracellular metabolite concentrations. Biotechnol. Bioeng. 2006; 94:585-95. [PubMed: 16511888]

191. Rao NN, Gomez-Garcia MR, Kornberg A. Inorganic polyphosphate: essential for growth and survival. Annu. Rev. Biochem. 2009; 78:605-47. [PubMed: 19344251]

192. Rebeck GW, Samson LD. Increased spontaneous mutation and alkylation sensitivity of Escherichia coli strains lacking the ogt $\mathrm{O}^{6}$-methylguanine DNA repair methyltransferase. J. Bacteriol. 1991; 173:2068-2076. [PubMed: 2002008]

193. Reddy M, Gowrishankar J. A genetic strategy to demonstrate the occurrence of spontaneous mutations in non-dividing cells within colonies of Escherichia coli. Genetics. 1997; 147:9911001. [PubMed: 9383047]

194. Reimers JM, Schmidt KH, Longacre A, Reschke DK, Wright BE. Increased transcription rates correlate with increased reversion rates in leuB and $\operatorname{argH}$ Escherichia coli auxotrophs. Microbiology. 2004; 150:1457-66. [PubMed: 15133107]

195. Ren L, Rahman MS, Humayun MZ. Escherichia coli cells exposed to streptomycin display a mutator phenotype. J. Bacteriol. 1999; 181:1043-4. [PubMed: 9922274]

196. Rhodius VA, Suh WC, Nonaka G, West J, Gross CA. Conserved and variable functions of the sigmaE stress response in related genomes. PLoS Biol. 2006; 4:e2. [PubMed: 16336047]

197. Rinken R, Thoms B, Wackernagel W. Evidence that recBC-dependent degradation of duplex DNA in Escherichia coli recD mutants involves DNA unwinding. J. Bacteriol. 1992; 174:54245429. [PubMed: 1322885]

198. Rodriguez C, Tompkin J, Hazel J, Foster PL. Induction of a DNA nickase in the presence of its target site stimulates adaptive mutation in Escherichia coli. J. Bacteriol. 2002; 184:5599-5608. [PubMed: 12270817]

199. Rodriguez RJ. Polyphosphate present in DNA preparations from filamentous fungal species of Colletotrichum inhibits restriction endonucleases and other enzymes. Anal. Biochem. 1993; 209:291-7. [PubMed: 8385889]

200. Rosche WA, Foster PL. The role of transient hypermutators in adaptive mutation in Escherichia coli. Proc. Natl. Acad. Sci. U.S.A. 1999; 96:6862-6867. [PubMed: 10359804]

201. Rosen R, Ron EZ. Proteome analysis in the study of the bacterial heat-shock response. Mass Spectrom. Rev. 2002; 21:244-65. [PubMed: 12533799]

202. Rosenberg SM, Harris RS, Torkelson J. Molecular handles on adaptive mutation. Mol. Microbiol. 1995; 18:185-189. [PubMed: 8709838]

203. Rosenberg SM, Hastings PJ. Adaptive point mutation and adaptive amplification pathways in the Escherichia coli Lac system: stress responses producing genetic change. J. Bacteriol. 2004; 186:4838-4843. [PubMed: 15262914]

204. Rosenberg SM, Longerich S, Gee P, Harris RS. Adaptive mutation by deletions in small mononucleotide repeats. Science. 1994; 265:405-407. [PubMed: 8023163]

205. Ross C, Pybus C, Pedraza-Reyes M, Sung HM, Yasbin RE, Robleto E. Novel role of $m f d$ : effects on stationary-phase mutagenesis in Bacillus subtilis. J. Bacteriol. 2006; 188:7512-20. [PubMed: 16950921]

206. Rosset R, Gorini L. A ribosomal ambiguity mutation. J. Mol. Biol. 1969; 39:95-112. [PubMed: 4938819]

207. Roth JR. Genetic adaptation: a new piece for a very old puzzle. Curr. Biol. 2010; 20:R15-7. [PubMed: 20152136]

208. Roth JR, Andersson DI. Adaptive mutation: how growth under selection stimulates Lac(+) reversion by increasing target copy number. J. Bacteriol. 2004; 186:4855-4860. [PubMed: 15262920]

209. Roth JR, Kofoid E, Roth FP, Berg OG, Seger J, Andersson DI. Regulating general mutation rates: examination of the hypermutable state model for Cairnsian adaptive mutation. Genetics. 2003; 163:1483-96. [PubMed: 12702691]

210. Roth JR, Kugelberg E, Reams AB, Kofoid E, Andersson DI. Origin of mutations under selection: the adaptive mutation controversy. Annu. Rev. Microbiol. 2006; 60:477-501. [PubMed: 16761951] 
211. Rouvière-Yaniv J, Kjeldgaard NO. Native Escherichia coli HU protein is a heterotypic dimer. FEBS Lett. 1979; 106:297-300. [PubMed: 227733]

212. Rudner R, Murray A, Huda N. Is there a link between mutation rates and the stringent response in Bacillus subtilis. Ann. N.Y. Acad. Sci. 1999; 870:418-422. [PubMed: 10415512]

213. Ryan FJ. Spontaneous mutation in non-dividing bacteria. Genetics. 1955; 40:726-738. [PubMed: 17247585]

214. Ryan FJ, Okada T, Nagata T. Spontaneous mutation in spheroplasts of Escherichia coli. J. Gen. Microbiol. 1963; 30:193-199. [PubMed: 13975747]

215. Sakai A, Nakanishi M, Yoshiyama K, Maki H. Impact of reactive oxygen species on spontaneous mutagenesis in Escherichia coli. Genes Cells. 2006; 11:767-78. [PubMed: 16824196]

216. Sakuraba H, Kawakami R, Ohshima T. First archaeal inorganic polyphosphate/ATP-dependent NAD kinase, from hyperthermophilic archaeon Pyrococcus horikoshii: cloning, expression, and characterization. Appl. Environ. Microbiol. 2005; 71:4352-8. [PubMed: 16085824]

217. Saumaa S, Tarassova K, Tark M, Tover A, Tegova R, Kivisaar M. Involvement of DNA mismatch repair in stationary-phase mutagenesis during prolonged starvation of Pseudomonas putida. DNA Repair (Amst). 2006; 5:505-14. [PubMed: 16414311]

218. Scaife J, Beckwith JR. Mutational alteration of the maximal level of Lac operon expression. Cold Spring Harb. Symp. Quant. Biol. 1966; 31:403-8. [PubMed: 4866390]

219. Schreiber G, Ron EZ, Glaser G. ppGpp-mediated regulation of DNA replication and cell division in Escherichia coli. Curr. Microbiol. 1995; 30:27-32. [PubMed: 7765879]

220. Schurig-Briccio LA, Farias RN, Rintoul MR, Rapisarda VA. Phosphate-enhanced stationaryphase fitness of Escherichia coli is related to inorganic polyphosphate level. J. Bacteriol. 2009; 191:4478-81. [PubMed: 19376858]

221. Sedgwick B, Bates PA, Paik J, Jacobs SC, Lindahl T. Repair of alkylated DNA: recent advances. DNA Repair (Amst). 2007; 6:429-42. [PubMed: 17112791]

222. Sedgwick B, Lindahl T. Recent progress on the Ada response for inducible repair of DNA alkylation damage. Oncogene. 2002; 21:8886-94. [PubMed: 12483506]

223. Seelke R, Kline B, Aleff R, Porter RD, Shields MS. Mutations in the recD gene of Escherichia coli that raise the copy number of certain plasmids. J. Bacteriol. 1987; 169:4841-4844. [PubMed: 3308857]

224. Shapiro JA. Observations on the formation of clones containing araB-lacZ cistron fusions. Mol. Gen. Genet. 1984; 194:79-90. [PubMed: 6233472]

225. Shiba T, Tsutsumi K, Yano H, Ihara Y, Kameda A, Tanaka K, Takahashi H, Munekata M, Rao $\mathrm{NN}$, Kornberg A. Inorganic polyphosphate and the induction of rpoS expression. Proc. Natl. Acad. Sci. U.S.A. 1997; 94:11210-11215. [PubMed: 9326588]

226. Sladewski TE, Hetrick KM, Foster PL. Escherichia coli Rep DNA helicase and error-prone DNA polymerase IV interact physically and functionally. Mol. Microbiol. 2011; 80:524-41. [PubMed: 21320186]

227. Slechta ES, Bunny KL, Kugelberg E, Kofoid E, Andersson DI, Roth JR. Adaptive mutation: General mutagenesis is not a programmed response to stress but results from rare coamplification of $\operatorname{din} B$ with lac. Proc. Natl. Acad. Sci. U.S.A. 2003; 100:12847-12852. [PubMed: 14559967]

228. Slupska MM, Baikalov C, Lloyd RG, Miller JH. Mutator tRNAs are encoded by the Escherichia coli mutator genes mutA and mutC: a novel pathway for mutagenesis. Proc. Natl. Acad. Sci. U.S.A. 2000; 93:4380-4385. [PubMed: 8633075]

229. Slupska MM, King AG, Lu LI, Lin RH, Mao EF, Lackey CA, Chiang JH, Baikalov C, Miller JH. Examination of the role of DNA polymerase proofreading in the mutator effect of miscoding tRNAs. J. Bacteriol. 1998; 180:5712-7. [PubMed: 9791123]

230. Smith PA, Romesberg FE. Combating bacteria and drug resistance by inhibiting mechanisms of persistence and adaptation. Nat. Chem. Biol. 2007; 3:549-56. [PubMed: 17710101]

231. Sonezaki S, Okita K, Oba T, Ishii Y, Kondo A, Kato Y. Protein substrates and heat shock reduce the DNA-binding ability of Escherichia coli Lon protease. Appl. Microbiol. Biotechnol. 1995; 44:484-8. [PubMed: 8597553]

232. Stahl FW. A unicorn in the garden. Nature (London). 1988; 335:112-113. [PubMed: 3412467] 
233. Stahl FW. Unicorns revisited. Genetics. 1992; 132:865-867. [PubMed: 1459440]

234. Storvik, K.; Foster, PL. unpublished

235. Storvik KA, Foster PL. The SMC-like protein complex SbcCD enhances DNA polymerase IVdependent spontaneous mutation in Escherichia coli. J. Bacteriol. 2011; 193:660-9. [PubMed: 21131491]

236. Strauss BS, Roberts R, Francis L, Pouryazdanparast P. Role of the $\operatorname{din} B$ gene product in spontaneous mutation in Escherichia coli with an impaired replicative polymerase. J. Bacteriol. 2000; 182:6742-6750. [PubMed: 11073920]

237. Streisinger G, Okada Y, Emrich J, Newton J, Tsugita A, Terzhagi E, Inouye M. Frameshift mutations and the genetic code. Cold Spring Harb. Symp. Quant. Biol. 1966; 31:77-84. [PubMed: 5237214]

238. Stumpf JD, Foster PL. Polyphosphate kinase regulates error-prone replication by DNA polymerase IV in Escherichia coli. Mol. Microbiol. 2005; 57:751-61. [PubMed: 16045619]

239. Sundin GW, Weigand MR. The microbiology of mutability. FEMS Microbiol. Lett. 2007; 277:11-20. [PubMed: 17714481]

240. Sung HM, Yasbin RE. Adaptive, or stationary-phase, mutagenesis, a component of bacterial differentiation in Bacillus subtilis. J. Bacteriol. 2002; 184:5641-53. [PubMed: 12270822]

241. Sung HM, Yeamans G, Ross CA, Yasbin RE. Roles of YqjH and YqjW, homologs of the Escherichia coli UmuC/DinB or Y superfamily of DNA polymerases, in stationary-phase mutagenesis and UV-induced mutagenesis of Bacillus subtilis. J. Bacteriol. 2003; 185:2153-60. [PubMed: 12644484]

242. Szekeres ES Jr. Woodgate R, Lawrence CW. Substitution of $m u c A B$ or $r u m A B$ for $u m u D C$ alters the relative frequencies of the two classes of mutations induced by a site-specific T-T cyclobutane dimer and the efficiency of translesion DNA synthesis. J. Bacteriol. 1996; 178:2559-63. [PubMed: 8626322]

243. Taddei F, Halliday JA, Matic I, Radman M. Genetic analysis of mutagenesis in aging Escherichia coli colonies. Mol. Gen. Genet. 1997; 256:277-281. [PubMed: 9393452]

244. Taddei F, Matic I, Radman M. cAMP-dependent SOS induction and mutagenesis in resting bacterial populations. Proc. Natl. Acad. Sci. U.S.A. 1995; 92:11736-11740. [PubMed: 8524839]

245. Tang MS, Wang TCV, Patrick MH. DNA turnover in buffer-held Escherichia coli and its effect on repair of UV damage. Photochem. Photobiol. 1979; 79:511-520. [PubMed: 375250]

246. Tark M, Tover A, Tarassova K, Tegova R, Kivi G, Horak R, Kivisaar M. A DNA polymerase V homologue encoded by TOL plasmid pWW0 confers evolutionary fitness on Pseudomonas putida under conditions of environmental stress. J .Bacteriol. 2005; 187:5203-13. [PubMed: 16030214]

247. Taverna P, Sedgwick B. Generation of an endogenous DNA-methylating agent by nitrosation in Escherichia coli. J. Bacteriol. 1996; 178:5105-5111. [PubMed: 8752326]

248. Tegova R, Tover A, Tarassova K, Tark M, Kivisaar M. Involvement of error-prone DNA polymerase IV in stationary-phase mutagenesis in Pseudomonas putida. J. Bacteriol. 2004; 186:2735-44. [PubMed: 15090515]

249. Thieringer HA, Jones PG, Inouye M. Cold shock and adaptation. BioEssays. 1998; 20:49-57. [PubMed: 9504047]

250. Timms AR, Muriel W, Bridges BA. A UmuD,C-dependent pathway for spontaneous G:C to C:G transversions in stationary phase Escherichia coli. Mutat. Res. 1999; 435:77-80. [PubMed: 10526218]

251. Tlsty TD, Albertini AM, Miller JH. Gene amplification in the lac region of E. coli. Cell. 1984; 37:217-24. [PubMed: 6327052]

252. Tompkins JD, Nelson JE, Hazel JC, Leugers SL, Stumpf JD, Foster PL. Error-prone polymerase, DNA polymerase IV, is responsible for transient hypermutation during adaptive mutation in Escherichia coli. J. Bacteriol. 2003; 185:3469-3472. [PubMed: 12754247]

253. Torkelson J, Harris RS, Lombardo MJ, Nagendran J, Thulin C, Rosenberg SM. Genome-wide hypermutation in a subpopulation of stationary-phase cells underlies recombination-dependent adaptive mutation. EMBO J. 1997; 16:3303-3311. [PubMed: 9214645] 
254. Tsui HCT, Feng G, Winkler ME. Negative regulation of $m u t S$ and $m u t H$ repair gene expression by the Hfq and RpoS global regulators of Escherichia coli K-12. J. Bacteriol. 1997; 179:74767487. [PubMed: 9393714]

255. Tsutsumi K, Munekata M, Shiba T. Involvement of inorganic polyphosphate in expression of SOS genes. Biochim. Biophys. Acta. 2000; 1493:73-81. [PubMed: 10978509]

256. Vijayakumar SR, Kirchhof MG, Patten CL, Schellhorn HE. RpoS-regulated genes of Escherichia coli identified by random lacZ fusion mutagenesis. J .Bacteriol. 2004; 186:8499-507. [PubMed: 15576800]

257. Wagner J, Nohmi T. Escherichia coli DNA polymerase IV mutator activity: genetic requirements and mutational specificity. J. Bacteriol. 2000; 182:4587-4595. [PubMed: 10913093]

258. Wang JD, Sanders GM, Grossman AD. Nutritional control of elongation of DNA replication by (p)ppGpp. Cell. 2007; 128:865-75. [PubMed: 17350574]

259. Weber H, Polen T, Heuveling J, Wendisch VF, Hengge R. Genome-wide analysis of the general stress response network in Escherichia coli: sigmaS-dependent genes, promoters, and sigma factor selectivity. J. Bacteriol. 2005; 187:1591-603. [PubMed: 15716429]

260. Williams AB, Foster PL. The Escherichia coli histone-like protein HU has a role in stationary phase adaptive mutation. Genetics. 2007; 177:723-35. [PubMed: 17720921]

261. Witkin EM, McCall JO, Volkert MR, Wermundsen IE. Constitutive expression of SOS functions and modulation of mutagenesis resulting from resolution of genetic instability at or near the recA locus of Escherichia coli. Mol. Gen. Genet. 1982; 185:43-50. [PubMed: 6211591]

262. Wolff E, Kim M, Hu K, Yang H, Miller JH. Polymerases leave fingerprints: analysis of the mutational spectrum in Escherichia coli rpoB to assess the role of polymerase IV in spontaneous mutation. J. Bacteriol. 2004; 186:2900-2905. [PubMed: 15090533]

263. Woodgate R, Ennis DG. Levels of chromosomally encoded Umu proteins and requirements for in vivo UmuD cleavage. Mol. Gen. Genet. 1991; 229:10-6. [PubMed: 1654503]

264. Wrande M, Roth JR, Hughes D. Accumulation of mutants in "aging" bacterial colonies is due to growth under selection, not stress-induced mutagenesis. Proc. Natl. Acad. Sci. U.S.A. 2008; 105:11863-8. [PubMed: 18701713]

265. Wright BE. Stress-directed adaptive mutations and evolution. Mol. Microbiol. 2004; 52:643-50. [PubMed: 15101972]

266. Wright BE, Longacre A, Reimers JM. Hypermutation in derepressed operons of Escherichia coli K-12. Proc. Natl. Acad. Sci. U.S.A. 1999; 96:5089-5094. [PubMed: 10220423]

267. Wu YH, Franden MA, Hawker JR Jr. McHenry CS. Monoclonal antibodies specific for the alpha subunit of the Escherichia coli DNA polymerase III holoenzyme. J. Biol. Chem. 1984; 259:12117-22. [PubMed: 6090455]

268. Yanofsky, C.; Crawford, IP.; Neidhardt, FC.; Ingraham, JL.; Magasanik, B.; Low, KB.; Schaechter, M.; Umbarger, HE. Escherichia coli and Salmonella typhimurium Cellular and Molecular Biology.. American Society for Microbiology; Washington, DC: 1987. The tryptophan operon; p. 1453-1472.

269. Yanofsky C, Ito J, Horn V. Amino acid replacements and the genetic code. Cold Spring Harb. Symp. Quant. Biol. 1966; 31:151-162. [PubMed: 4866372]

270. Yeiser B, Pepper ED, Goodman MF, Finkel SE. SOS-induced DNA polymerases enhance longterm survival and evolutionary fitness. Proc. Natl. Acad. Sci. U.S.A. 2002; 99:8737-8741. [PubMed: 12060704]

271. Yura, T.; Kanemori, M.; Morita, MT.; Storz, G.; Hengge-Aronis, R. Bacterial Stress Responses. ASM Press; Washington: 2000. The heat shock response: regulation and function; p. 3-18.

272. Zechiedrich EL, Khodursky AB, Bachellier S, Schneider R, Chen D, Lilley DM, Cozzarelli NR. Roles of topoisomerases in maintaining steady-state DNA supercoiling in Escherichia coli. J. Biol. Chem. 2000; 275:8103-13. [PubMed: 10713132]

273. Zhang H, Gomez-Garcia MR, Shi X, Rao NN, Kornberg A. Polyphosphate kinase 1, a conserved bacterial enzyme, in a eukaryote, Dictyostelium discoideum, with a role in cytokinesis. Proc. Natl. Acad. Sci. U.S.A. 2007; 104:16486-91. [PubMed: 17940044]

274. Zhang H, Ishige K, Kornberg A. A polyphosphate kinase (PPK2) widely conserved in bacteria. Proc. Natl. Acad. Sci. U.S.A. 2002; 99:16678-83. [PubMed: 12486232] 
275. Zhao J, Winkler ME. Reduction of GC to TA transversion mutation by overexpression of MutS in Escherichia coli K-12. J. Bacteriol. 2000; 182:5025-8. [PubMed: 10940054]

276. Zhou Y, Gottesman S. Regulation of proteolysis of the stationary-phase sigma factor RpoS. J. Bacteriol. 1998; 180:1154-1158. [PubMed: 9495753]

277. Zhou Y, Gottesman S, Hoskins JR, Maurizi MR, Wickner S. The RssB response regulator directly targets RpoS for degradation by ClpXP. Gene. Dev. 2001; 15:627-637. [PubMed: 11238382] 


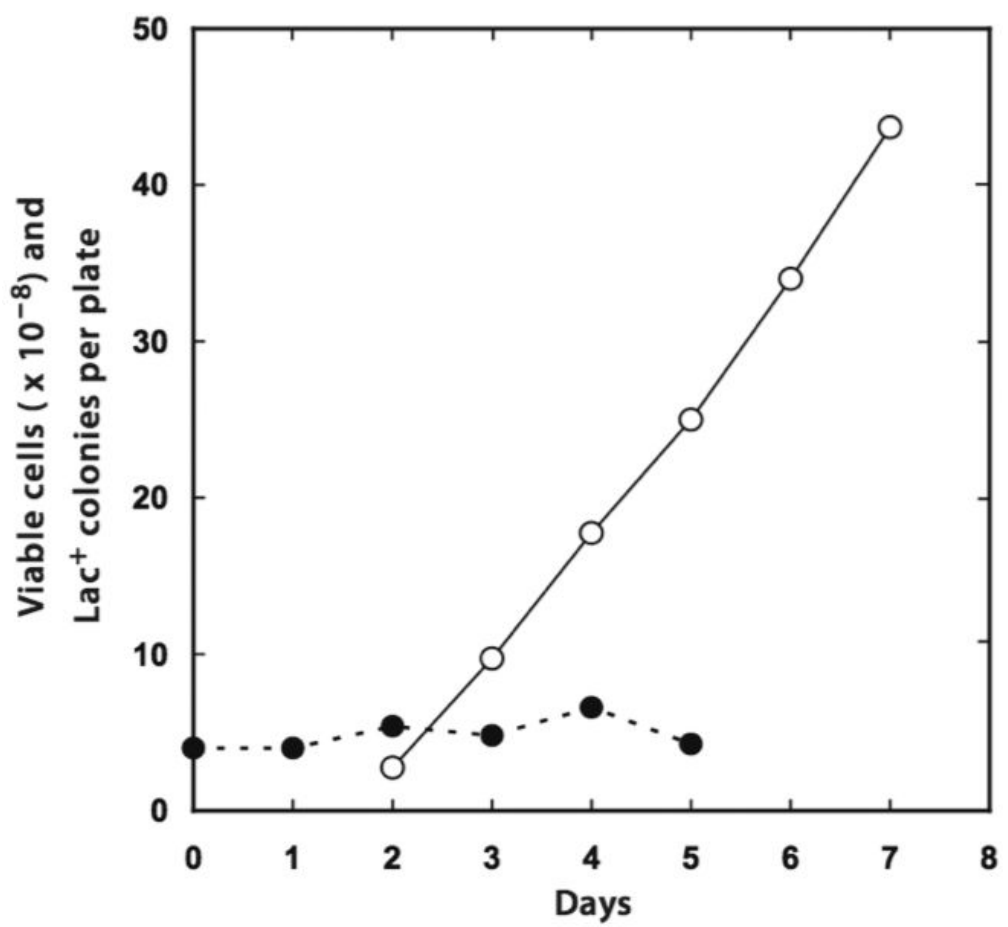

Figure 1.

Adaptive mutation to $\mathrm{Lac}^{+}$in E. coli strain FC40. Six cultures of FC40 were grown to saturation in liquid M9-glycerol medium. Aliquots containing 3 X $10^{8}$ FC40 cells were mixed with $10^{9}$ scavenger cells and spread on M9-lactose plates. On each day, small circular samples were removed from one of each set of six plates (avoiding any visible $\mathrm{Lac}^{+}$ colonies) and were vortexed with $1 \mathrm{ml} \mathrm{M9}$; the viable titer of FC40 in these suspensions was assayed on rifampicin-peptone plates (filled circles). The $\mathrm{Lac}^{+}$colony counts (open circles) are the averages for 23 plates. (Reproduced with permission from The Genetics Society of America [43].) 


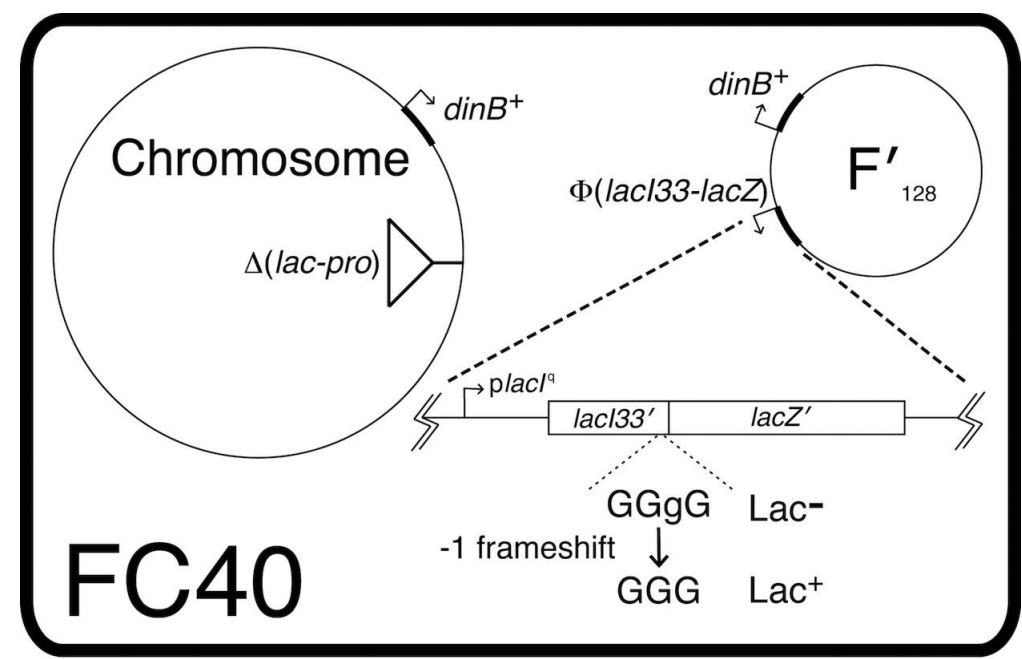

Figure 2.

The genetic structure of E. coli strain FC40. FC40 is deleted for the (lac-pro) region of the chromosome. A region of chromosomal DNA on the $\mathrm{F}^{\prime} 128$ episome, which includes the $\Phi$ (lacI33-lacZ) allele, complements this deletion. The $\Phi$ (lacI33-lacZ) allele is a fusion of lacI to lacZ and is expressed from the constitutive $l a c I^{q}$ promoter. This fusion normally encodes a functional $\beta$-galactosidase protein; however, FC40 is $\mathrm{Lac}^{-}$due to insertion of an extra guanine residue in the lacI region of the fusion. Adaptive $\mathrm{Lac}^{+}$reversions occur when a -1 frameshift restores the normal reading frame in the $\Phi$ (lacl33-lacZ) allele (see text for additional details). 


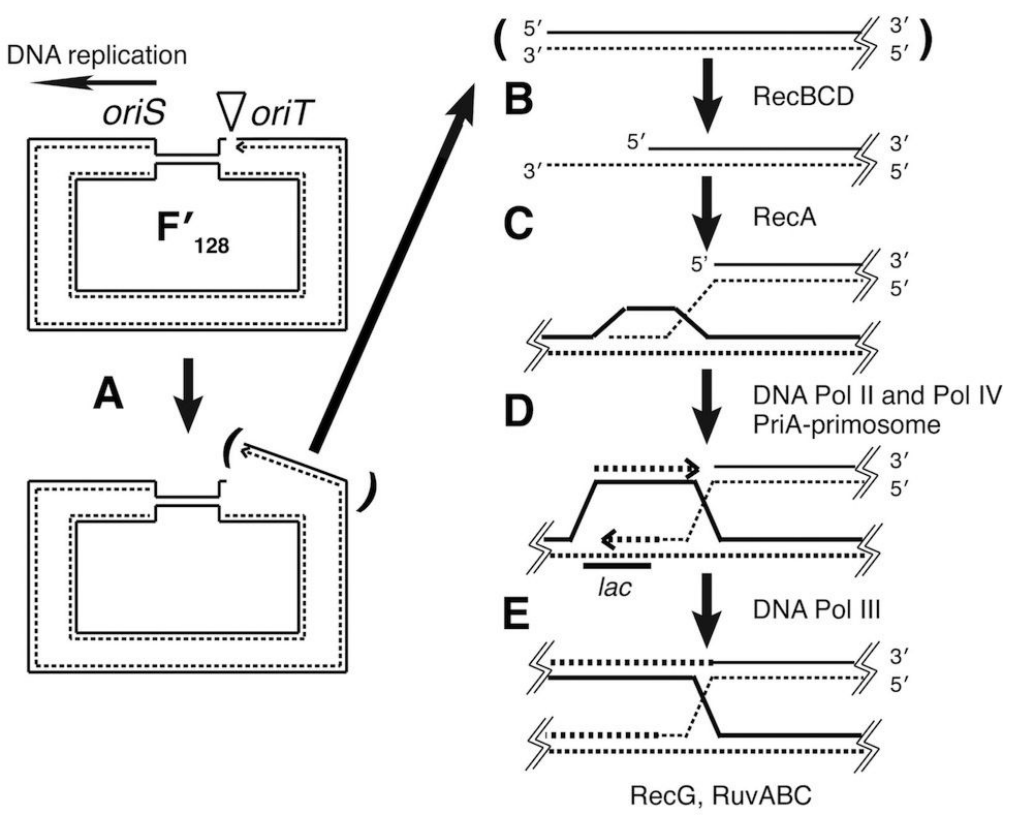

Figure 3.

The recombination-dependent model for adaptive mutation to $\mathrm{Lac}^{+}$. A replication fork initiated at the vegetative origin, oriS, on $\mathrm{F}^{\prime} 128$ collapses when it arrives at a nick at the conjugal origin, oriT. A. Collapse of the replication fork creates a double-strand end. B. RecBCD processes the double-strand end to form a 3' single-strand end. C. RecA catalyzes the invasion of the $3^{\prime}$ single-strand end into a homologous region of duplex DNA. D. PriAdependent DNA synthesis is initiated from the invading $3^{\prime \prime}$ end by DNA Pol IV or Pol II and a Holliday junction is formed. E. A normal replication fork is re-established with DNA Pol III. The Holliday junction is processed and resolved by RuvABC. Adaptive $\mathrm{Lac}^{+}$reversions occur when error-prone DNA synthesis extends into the lac region on the episome and introduces a -1 frameshift. 


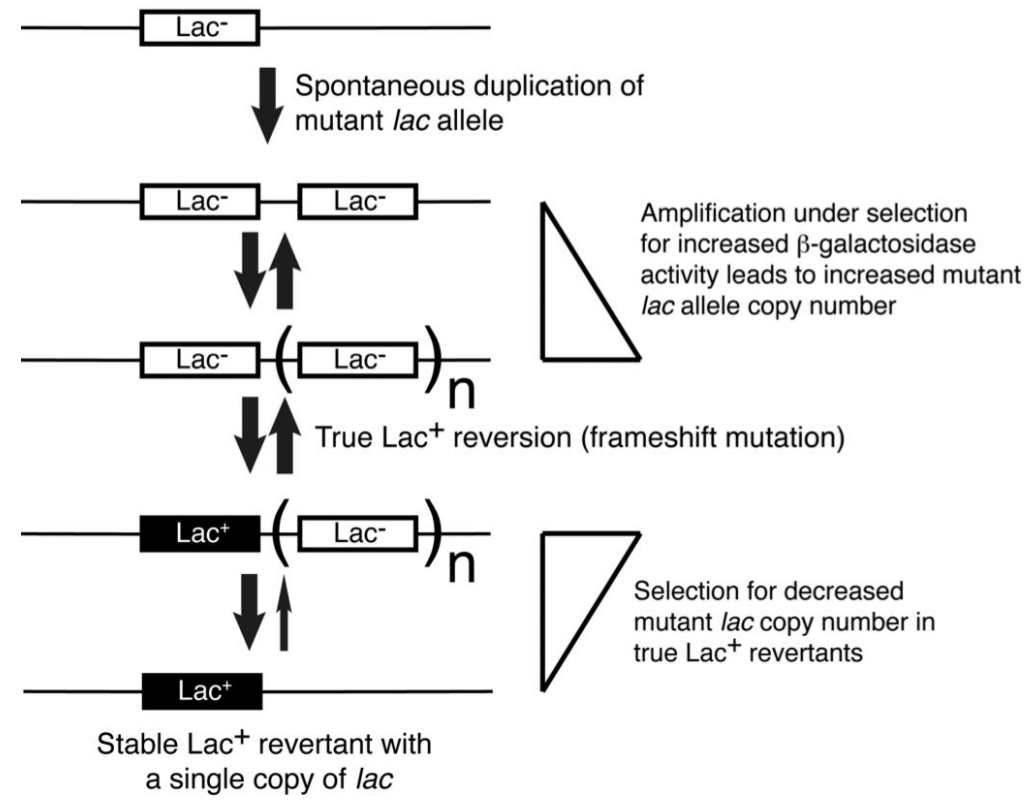

Figure 4.

The amplification-dependent model for adaptive mutation to $\mathrm{Lac}^{+}$. The mutant lac allele on $\mathrm{F}^{\prime} 128$ is spontaneously duplicated. During incubation on lactose, selection for increased $\beta$ galactosidase activity favors further amplification of the $\mathrm{lac}$ region. A true $\mathrm{Lac}^{+}$reversion occurs in a copy of the mutant lac allele in the amplified array. Once a true $\mathrm{Lac}^{+}$allele is present, the selective pressure promoting lac amplification is relieved and the lac copy number decreases. Finally, a stable $\mathrm{Lac}^{+}$revertant cell with a single copy of lac is formed and this cell grows to form a colony on the minimal lactose plate. (Adapted from Annual Reviews in Microbiology [210] with permission from the publisher.) 


\section{Table 1}

\section{Stress-response Regulation of Pol IV}

\begin{tabular}{lll}
\hline Factor & Stress-response & Type of Regulation \\
\hline RecA/LexA & SOS & Transcriptional activation/repression \\
RpoS & General stress response & Direct transcriptional activation \\
GroE & Heat-shock response & Enhancement of protein levels \\
Ppk & Nutritional deprivation & $\begin{array}{l}\text { Probably direct; required for full mutagenic activity and translesion } \\
\text { bypass }\end{array}$ \\
HU & Growth phase; nutrient limitation; & $\begin{array}{l}\text { Indirect, Huaß heterodimer required for full mutagenic activity } \\
\text { cold-shock }\end{array}$ \\
Rep DNA helicase & None known & $\begin{array}{l}\text { Probably direct; enhances polymerase activity, required for full } \\
\text { mutagenic activity }\end{array}$ \\
\hline
\end{tabular}




\section{Table 2}

Genetic characteristics of adaptive mutation in FC40

\begin{tabular}{|c|c|c|c|}
\hline Gene & Gene product & Inducing stress response & Reference(s) \\
\hline \multicolumn{4}{|c|}{ Genes Required for Adaptive Mutation } \\
\hline $\operatorname{rec} A^{+}$ & DNA recombinase & SOS & $(43,74)$ \\
\hline $\operatorname{rec} B C^{+}$ & DNA double-strand end exonuclease & Extracytoplasmic stress $^{a}$ & $(82,106,196)$ \\
\hline $\operatorname{ruvAB^{+}}$ and $r u v C^{+}$ & Holiday-junction resolvase & SOS & $(86,107)$ \\
\hline priA $^{+}$ & Replication-restart primosome & None known & (79) \\
\hline nusA & Transcription factor & Cold-shock & $(52,249)$ \\
\hline \multicolumn{4}{|c|}{ Genes Required for the Maximum Rate of Adaptive Mutation } \\
\hline $\operatorname{recF}^{+}$ & DNA single-strand and double-strand binding & SOS & $(79,162)$ \\
\hline $\operatorname{din} B^{+}$ & Error-prone DNA Pol IV & SOS, general stress & $(72,163)$ \\
\hline Conjugal functions & Conjugal replication and transfer & Growth phase & $(84,85,90,189)$ \\
\hline$r p o S^{+}$ & Transcription specificity factor & General stress & $(145,153)$ \\
\hline$r p o E$ & Transcription specificity factor & Extracytoplasmic stress & (93) \\
\hline $\operatorname{groE}^{+}$ & Protein chaperone & Heat-shock & (146) \\
\hline$p p k^{+}$ & Polyphosphate Kinase & Nutritional deprivation & (238) \\
\hline hирA, hирB & Histone-like protein $\mathrm{HU}$ & Growth phase, nutrient limitation, cold-shock & (260) \\
\hline \multicolumn{4}{|c|}{ Defects that Enhance Adaptive Mutation } \\
\hline $\operatorname{rec} G$ & Holiday-junction resolvase; helicase & SOS & $(86,107)$ \\
\hline polA1 & DNA polymerase I & None known & (79) \\
\hline $\operatorname{rec} D$ & 5 ' to 3' helicase subunit of RecBCD & Extracytoplasmic stress ${ }^{a}$ & $(82,106)$ \\
\hline mutS, mutL & Mismatch repair & General Stress & $(80,83,154,204)$ \\
\hline polB & DNA Pol II & SOS & (68) \\
\hline
\end{tabular}

${ }^{a}$ The $\operatorname{rec} B$ and $r e c D$ genes are in an operon that is regulated by RpoE, the extracytoplasmic stress sigma factor $(82,106,196)$. The $\operatorname{rec} C$ gene is not in the same operon and is not known to be regulated by RpoE. Thus, it is not clear if extracytoplasmic stress increases the levels of active RecBC or RecBCD enzyme. 


\section{Table 3}

Comparison of the recombination-dependent and amplification-dependent models

\begin{tabular}{|c|c|c|}
\hline Feature & Recombination-dependent model (ref) & Amplification-dependent model (ref) \\
\hline Stress-induced mutagenesis & DNA synthesis by Pol IV $(72,163)$ & None (209) \\
\hline Initiating event & $\begin{array}{l}\text { Nick at } \text { oriT initiates double strand break repair } \\
\text { pathway }(84,185,198)\end{array}$ & $\begin{array}{l}\text { Rare duplication of lac allele promotes } \\
\text { amplification (7) }\end{array}$ \\
\hline $\begin{array}{l}\text { Requirement for leaky lac } \\
\text { expression }\end{array}$ & $\begin{array}{l}\text { Slow metabolism supports occasional firing of episomal } \\
\text { replication origins (76) }\end{array}$ & $\begin{array}{l}\text { Slow growth under selection favors lac } \\
\text { amplification }(7)\end{array}$ \\
\hline $\begin{array}{l}\text { Requirement for recombination } \\
\text { functions }\end{array}$ & $\begin{array}{l}\text { Repair of double strand breaks leading to } \mathrm{Lac}^{+} \\
\text {reversions during repair DNA synthesis }(86,107)\end{array}$ & Amplification of the lac region (210) \\
\hline $\begin{array}{l}\text { Requirement for conjugal } \\
\text { functions }\end{array}$ & Production of nick at $\operatorname{oriT}(84,185,198)$ & $\begin{array}{l}\text { Production of double strand ends that promote } \\
\text { amplification (210) }\end{array}$ \\
\hline $\begin{array}{l}\text { Requirement for lac location } \\
\text { on the episome }\end{array}$ & $\begin{array}{l}\text { DNA replication from F replication origin results in } \\
\text { double strand break at nicked oriT }(84,185,198) ; 100 \text { - } \\
\text { fold higher mutation rate on the episome }(41,76,84 \text {, } \\
189,200)\end{array}$ & $\begin{array}{l}\text { High recombination rate of the episome favors } \\
\text { duplication and amplification }(210)\end{array}$ \\
\hline Requirement for Pol IV & $\begin{array}{l}\text { Pol IV-dependent DNA synthesis results in frameshift } \\
\text { mutations leading to } \mathrm{Lac}^{+} \text {reversion }(72,163)\end{array}$ & $\begin{array}{l}\text { Co-amplification of } \operatorname{din} B^{+} \text {with } l a c \text { leads to } \\
\text { hypermutating sub-population ( } 227)\end{array}$ \\
\hline Requirement for RpoS & RpoS required to induce Pol IV (145) & $\begin{array}{l}\text { RpoS required for growth under selection, tra } \\
\text { operon expression, maximum rate of } \\
\text { amplification, and/or SOS induction (210) }\end{array}$ \\
\hline Causes of hypermutation & $\begin{array}{l}\text { Decline in mismatch repair and increased Pol IV } \\
\text { expression }(163,200,252)\end{array}$ & Amplification of $\operatorname{din} B$ with the $l a c$ allele (227) \\
\hline
\end{tabular}

